Tetrahedron

journal homepage: www.elsevier.com

\title{
Soft Ruthenium and Hard Brønsted Acid Combined Catalyst for Efficient Cleavage of Allyloxy Bonds. Application to Protecting Group Chemistry.
}

\author{
Shinji Tanaka ${ }^{a}$, Yusuke Suzuki ${ }^{a}$, Hajime Saburi ${ }^{a}$, and Masato Kitamura ${ }^{a}$ \\ ${ }^{a}$ Graduate School of Pharmaceutical Sciences, Graduate School of Science, and Research Center for Materials Science, Nagoya University, Chikusa, Nagoya \\ 464-8601, Japan
}

\begin{abstract}
ARTICLE INFO
ABSTRACT

Article history:

Received

Received in revised form

Accepted

Available online

Keywords:

We show that a monocationic $\mathrm{CpRu}$ (II) complex of quinaldic acid (QAH) and a monocationic $\mathrm{CpRu}(\mathrm{IV})($-allyl)QA complex catalyze efficient cleavage of the allyloxy bond in allyl ethers, allyl esters, allyl carbonates, and allyl carbamates in methanol without the need for additional nucleophiles. The only co-product is volatile allyl methyl ether, enhancing operational simplicity during isolation of the deprotected alcohols, acids, and amines. This clean and highperformance catalytic system should contribute to protecting group chemistry during the multistep synthesis of pharmaceutically important natural products. Full details of this system, including the mechanism, are reported.
\end{abstract}

Allyl Group

Deprotection

Ruthenium

Quinaldic acid

Catalysis
2009 Elsevier Ltd. All rights reserved.

\section{Introduction}

Protecting groups (PGs) are the unsung heroes or heroines of chemistry. This detail is barely acknowledged in the retrosynthetic analysis of complicated natural and unnatural products, but it would not be too strong to say that accomplishing total synthesis is impossible without PGs, even in the 21 st century with its variety of highly sophisticated synthetic methods. ${ }^{1}$ Fig. 1 illustrates the general process for the protection of a function, $\mathbf{A}$, in the conversion of $\mathbf{B}$ to $\mathbf{Z}$. As is standard, $\mathbf{A}$ is first protected by a PG (red circle), and then the function $\mathbf{B}$ is subjected to a series of target reactions. Finally, $\mathbf{A}$ is deprotected by the action of reagents (black sphere) to give the desired product together with the co-product. High stability of the PG under various reaction conditions, as well as facile and chemoselective removal of the PG on demand, is essential. Furthermore, easy separation of the excess reagent and accompanying co-product from the desired product is also required. These requirements become even more stringent during the synthesis of polar biomolecular compounds such as peptides, nucleotides, and polysaccharides.

Among more than a thousand PGs invented so far, we have revisited the allyl (All) group for protecting an alcohol as an allyl ether, which has a structure as simple as that of an acetyl group and has higher stability toward both acidic and basic conditions. This chemical stability, however, often causes difficulty in

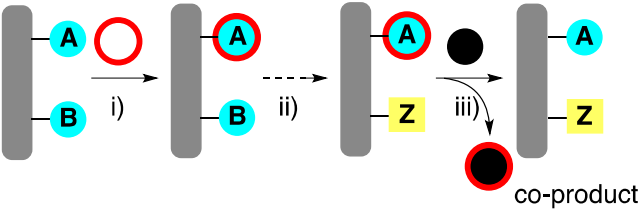

a 1,3-hydrogen shiftacidic hydrolysis or oxidative cleavage

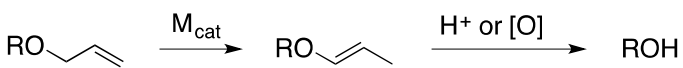

b $\pi$-allyl formation, nucleophilic cleavage

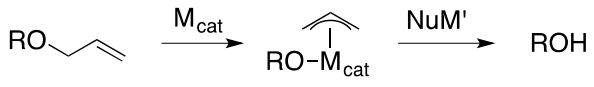

c oxidative cleavage

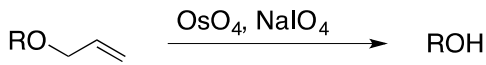

Fig. 1. Protecting group (PG) chemistry and the utility of allyl PG for alchols in organic synthesis. i) Protection. ii) Target function transformation from $\mathbf{B}$ to $\mathbf{Z}$. iii) Deprotection. Red circle: protecting group. Black sphere: reagent for deprotection. Black sphere in red circle: co-product.

Corresponding author. Tel.: +0-000-000-0000; fax: +0-000-000-0000; e-mail: author@university.edu 
deprotection or deallylation under mild conditions. As shown in Fig. 1a, the most popular approach to deprotection is Corey's method: ${ }^{2} \mathrm{RhCl}\left(\mathrm{P}\left(\mathrm{C}_{6} \mathrm{H}_{5}\right)_{3}\right)_{3}$ catalyzes a 1,3-hydrogen shift of the allyl ether to the corresponding alkenyl ether, which is then either hydrolyzed under acidic conditions or oxidatively cleaved. $\left[\operatorname{Ir}\left(\mathrm{P}\left(\mathrm{C}_{6} \mathrm{H}_{5}\right)_{2}\left(\mathrm{CH}_{3}\right)\right)_{2}(\mathrm{cod})\right] \mathrm{PF}_{6}$ reported by van Boom in 1980 shows higher catalytic performance. ${ }^{3}$ The types of one-step deprotection shown in Fig. 1b and Fig. 1c are simple, and many methods have been invented on the basis of Tsuji's Pd -allyl chemistry, ${ }^{4} \mathrm{Ni}$-allyl chemistry, ${ }^{5}$ and Os-catalyzed oxidative cleavage. $^{6}$

A major disadvantage common to all of these methods is that an excess amount of acids, bases, oxidizing reagents, or reducing reagents is required, complicating the reaction system. The ideal approach would clearly be the "No additive, One step," process shown in Fig. 1b, but such a catalytic system has not been attained. We therefore aimed to develop an optimal process that performs direct cleavage of the allyl ether under very mild conditions, and ultimately attained a monocationic $\mathrm{CpRu}(\mathrm{II})$ complex of quinaldic acid (QAH) and a monocationic $\mathrm{CpRu}(\mathrm{IV})($-allyl)QA complex. The present article describes full details of the screening results establishing $\mathrm{CpRu}^{+} / \mathrm{QAH}-$ catalyzed deallylation/allylation ${ }^{7}$ and a mechanistic study of this process.

\section{Results and discussion}

\subsection{Catalyst design concept}

We previously established a leading concept for the design of a molecular catalyst, "intramolecular metathesis-type donoracceptor bifunctional catalyst" (Intramol-MDACat), via the detailed mechanistic study of catalytic asymmetric 1,2-addition of diorganozincs to aldehydes. ${ }^{8}$ This concept realized a new type of asymmetric reaction including reduction, ${ }^{9}$ 1,4-addition of diorganozincs to enones, ${ }^{10}$ and others. ${ }^{11}$ Furthermore, the Intramol-MDACat concept has been extended to "IntermolMDACat" and to a "soft transition metal/hard Brønsted acidcombined catalyst" to achieve the efficient asymmetric hydrogenation of -keto esters. ${ }^{12}$

With this approach in mind, we designed a concept catalyst for allyloxy bond cleavage on the basis of a "intramolecular redox-mediated donor-acceptor bifunctional catalyst" (IntramolRDACat), as shown in Fig. 2. Here, the central transition metal $\mathrm{M}(n)$ is coordinated by $\mathbf{L}_{\mathbf{s}}-\mathbf{L}_{\mathbf{h}} \mathrm{H}\left(\mathbf{L}_{\mathbf{s}}\right.$, soft ligating atom; $\mathbf{L}_{\mathbf{h}}$, hard ligating atom) and a monoanionic and highly electron-donative

5 cyclopentadienyl $(\mathrm{Cp})$ ligand, endowing the $\mathrm{M}$ complex with a soft coordination site and a hydrogen-bond donor site. In this soft $\mathrm{M} /$ hard $\mathrm{H}^{+}$combined system, the hard oxygen atom of an allyl ether substrate would interact with $\mathrm{H}^{+}$, while the soft $\mathrm{C}=\mathrm{C}$ double bond would coordinate to $\mathrm{M}$ as a ${ }^{2}$ ligand. Enhancement of the electrophilicity or acceptability of the allyl moiety synergistically cooperates with the high nucleophilicity or donicity of the $\mathrm{CpM}(n)$ moiety, thereby facilitating movement of the substrate/catalyst complex to a ${ }^{+}-_{-}{ }^{+}-_{-}^{-}{ }^{+}{ }^{-}$chargealternating transition state involving $\mathrm{M}(n)$ oxidation. Such stabilization of the transition state would result in easy generation of the corresponding -allyl $\operatorname{CpM}(n+2)$ moiety. In addition, introduction of $\mathrm{Cp}$ and the bidentate property of $\mathbf{L}_{\mathbf{s}}-\mathbf{L}_{\mathbf{h}} \mathrm{H}$ should prevent self-aggregation of the catalyst, which often causes catalyst deactivation. Lastly, if the -allyl complex can react with $\mathrm{CH}_{3} \mathrm{OH}$, which could be used as a possible solvent, the $\mathrm{CpM}\left(\mathbf{L}_{\mathbf{s}}-\mathbf{L}_{\mathbf{h}} \mathrm{H}\right)$ catalyst would be regenerated alongside liberation of the deprotected alcohols and allyl methyl ether $\left(\mathrm{CH}_{3} \mathrm{OAll}\right)$ as the co-product, which could be easily removed simply by evaporation. This concept catalyst would be applicable to allyl esters, allyl carbonates, and allyl carbamates.

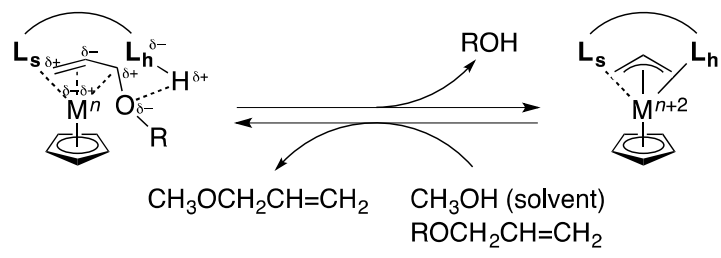

Fig. 2. Concept catalyst designed on the basis of "intramolecular redoxmediated donor-acceptor bifunctional catalyst (Intramol-RDACat)." $\mathbf{L}_{\mathbf{s}}$ : soft ligating atom. $\mathbf{L}_{\mathbf{h}}$ : hard ligating atom.

\subsection{Screening of $\mathbf{L}_{s}-\boldsymbol{L}_{h} H$ ligands}

Initially, the central metal was selected as $\mathrm{Ru}(\mathrm{II})$ in $\left[\mathrm{RuCp}\left(\mathrm{CH}_{3} \mathrm{CN}\right)_{3}\right] \mathrm{PF}_{6}(\mathbf{1})$ on the basis of our finding in 2002 that $\left[\mathrm{RuCp}\left(\mathrm{P}\left(\mathrm{C}_{6} \mathrm{H}_{5}\right)_{3}\right)\left(\mathrm{CH}_{3} \mathrm{CN}\right)_{2}\right] \mathrm{PF}_{6}$ prepared from 1 and $\mathrm{P}\left(\mathrm{C}_{6} \mathrm{H}_{5}\right)_{3}$ catalyzes the allyloxy bond cleavage of allyl esters. ${ }^{13}$ The catalyst screening was combinatorially conducted by using the customized automated synthesizer Chemspeed, ${ }^{14-15}$ which has five reaction blocks each containing 16 reaction vessels, and can be used under an inert Ar atmosphere. Forty-eight commercially available ligands L1-L48 (except for L36), used in a combination of $\mathbf{L}_{\mathbf{s}}\left(\mathrm{sp}^{3} \mathrm{P}, \mathrm{sp}^{2} \mathrm{~N}, \mathrm{sp}^{3} \mathrm{~N}\right.$, and others) with $\mathbf{L}_{\mathbf{h}} \mathrm{H}\left(\mathrm{COOH}, \mathrm{OH}, \mathrm{NH}_{2}\right.$, and no proton), were screened simultaneously under the following ideal conditions for alcohol deprotection: $\left[\mathrm{C}_{6} \mathrm{H}_{5^{-}}\right.$ $\left.\mathrm{CH}_{2} \mathrm{CH}_{2} \mathrm{OCH}_{2} \mathrm{CH}=\mathrm{CH}_{2}\left(\mathrm{C}_{6} \mathrm{H}_{5} \mathrm{CH}_{2} \mathrm{CH}_{2} \mathrm{OAll}(2)\right)\right]=100 \mathrm{mM} ;[\mathbf{1}]$ $=1 \mathrm{mM} ;\left[\mathbf{L}_{\mathbf{s}}-\mathbf{L}_{\mathbf{h}} \mathrm{H}\right]=1 \mathrm{mM}$; solvent, $\mathrm{CH}_{3} \mathrm{OH} ; 30{ }^{\circ} \mathrm{C} ; 3 \mathrm{~h}$. The Chemspeed system automatically mixed the $\mathrm{CH}_{3} \mathrm{OH}$ solutions of the $\mathbf{L}_{\mathbf{s}}-\mathbf{L}_{\mathbf{h}} \mathrm{H}$ ligands, 1, and $\mathrm{C}_{6} \mathrm{H}_{5} \mathrm{CH}_{2} \mathrm{CH}_{2} \mathrm{OAll}$ (2) in the reaction vessels, and sampled the reaction mixtures in a programed way. $\mathrm{GC}$ analysis was used to determine the yields of deprotected alcohol 3 and 1,3-hydrogen shift side product 4 (column, DBWAX $(0.25 \mathrm{~mm} \times 15 \mathrm{~m})$ as follows: temp., $50{ }^{\circ} \mathrm{C}+10^{\circ} \mathrm{C} / \mathrm{min}$; $t_{\mathrm{R}}, 6.0 \mathrm{~min}(2), 4.0 \mathrm{~min}(3)$, and $\left.4.5 \mathrm{~min}(4)\right)$. Fig. 3 shows the results. 2-Pyridinecarboxylic acid $(\mathrm{PAH} ; \mathrm{PA}$ indicates 2pyridinecarboxylate) quantitatively afforded 3. 8-Hydroxyl quinoline derivatives also showed some acceleration effect. Sulfides and azoles showed almost no reactivity, and phosphines tended to isomerize the allyl group to the corresponding alkenyl ether 4.

As shown in Table 1, the ligand structure-reactivity relationship was further investigated by shortening the reaction time to $1 \mathrm{~h}$ using the particularly highly reactive $\mathrm{PAH}$ as the starting point (entry 1). Neither pyridine nor benzoic acid, nor a 1:1 mixture of pyridine and benzoic acid showed an acceleration effect (entries 2-4). No reaction proceeded when the location of $\mathrm{COOH}$ in $\mathrm{PAH}$ was changed from $\mathrm{C}(2)$ to $\mathrm{C}(3)$ or $\mathrm{C}(4)$ (entries 5 and 6) or when $\mathrm{H}^{+}$was removed from $\mathrm{PAH}$ as PANa (sodium 2picolinate) or $\mathrm{PACH}_{3}$ (methyl 2-piclolinate) (entries 7 and 8). Replacement of the carboxyl group with a hydroxymethyl or aminomethyl group also resulted in no reaction, although a proton is located in the same position as the carboxyl group (entries 9 and 10). Quinoline-8-carboxylic acid, in which the $\operatorname{sp}^{2} \mathrm{~N}$ atom and $\mathrm{H}^{+}$are located in a 1,6 manner rather than the 1,5 manner of $\mathrm{PAH}$, showed no reactivity (entry 11). The presence of an electron-withdrawing substituent at the $\mathrm{C}(4)$ position of the pyridine ring of $\mathrm{PAH}$ tended to increase the reactivity with values of $27 \%\left(4-\mathrm{CH}_{3} \mathrm{O}\right), 39 \%(4-\mathrm{H}), 50 \%(4-\mathrm{Cl}), 54 \%\left(4-\mathrm{CF}_{3}\right)$, and $59 \%\left(4-\mathrm{NO}_{2}\right)$ (entries 1 and 12-15). Introduction of $\mathrm{PO}(\mathrm{OH})_{2}$ $\left(\mathrm{p} K_{\mathrm{a}}\right.$ ca. 1.5) instead of $\mathrm{COOH}\left(\mathrm{p} K_{\mathrm{a}}\right.$ ca. 5.4) in PAH enhanced the reactivity; however, further increasing the acidity by replacing $\mathrm{COOH}$ with $\mathrm{SO}_{3} \mathrm{H}\left(\mathrm{p} K_{\mathrm{a}}\right.$ ca. -3$)$ resulted in deceleration (entries 


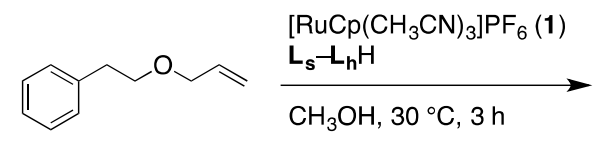

2

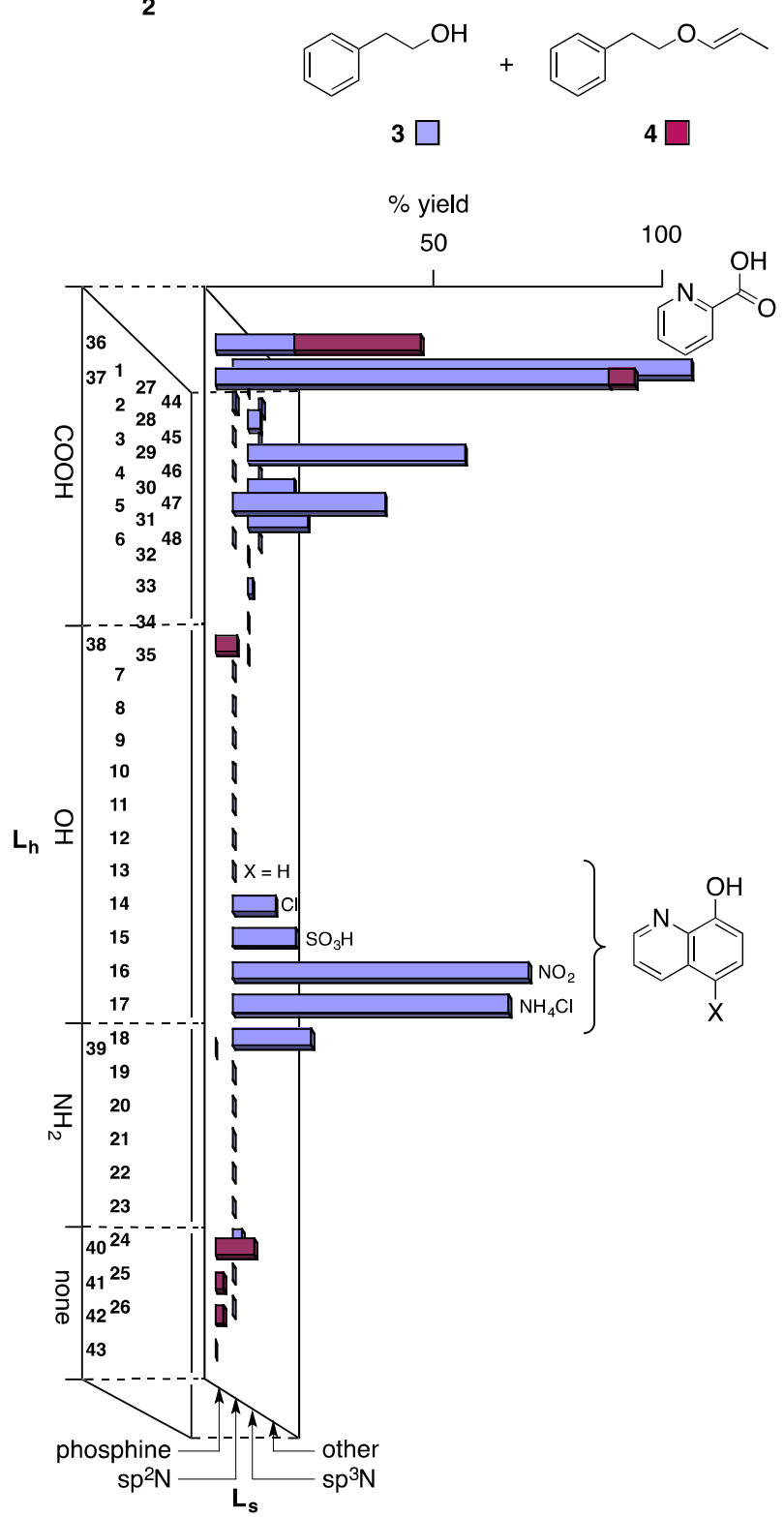

Fig. 3. Screening of $\mathbf{L}_{\mathbf{s}}-\mathbf{L}_{\mathbf{h}} \mathrm{H}$ under ideal conditions of [2] $=100 \mathrm{mM}$; [1] $=$ $1 \mathrm{mM} ;\left[\mathbf{L}_{\mathbf{s}}-\mathbf{L}_{\mathbf{h}} \mathrm{H}\right]=1 \mathrm{mM} ; \mathrm{CH}_{3} \mathrm{OH} ; 30^{\circ} \mathrm{C} ; 3 \mathrm{~h}$. The $\mathrm{x}$-coordinate shows the functional group of $\mathbf{L}_{\mathbf{h}}$ moiety. "None" indicates no functional group. The $\mathrm{y}$-coordinate corresponds to $\mathbf{L}_{\mathbf{s}}$ moiety such as sulfide, azole, amine, pyridine, and phosphine. The vertical axis shows the \% yields of the products (light blue-colored bar for the desired phenylethyl alcohol (3), and the purple bar for the undesired 1,3-hydrogen shift product (4). The structures of efficient ligands were drawn in the graph. For the structures of other ligands, see Experimentals. The numbers $1-48$ in the graph correspond to $\mathrm{L} 1-\mathrm{L} 48$.

16 and 17) (vide infra). Fusion of a benzene ring at $\mathrm{C}(3) / \mathrm{C}(4)$ or $\mathrm{C}(4) / \mathrm{C}(5)$ of $\mathrm{PAH}$ led to deceleration, while the most impressive enhancement in reactivity was attained with quinaldic acid (QAH, 2-quinolinecarboxylic acid; QA indicates 2and $\mathrm{C}(6)$ of PAH (entries 18-20): in this case, the reaction was completed within $1 \mathrm{~h}$. The results in Table 1 clearly indicate
Table 1. Ligand structure-reactivity relationship in the deallylation of $\mathrm{C}_{6} \mathrm{H}_{5} \mathrm{CH}_{2} \mathrm{CH}_{2} \mathrm{OAll}$ (2) to $\mathrm{C}_{6} \mathrm{H}_{5} \mathrm{CH}_{2} \mathrm{CH}_{2} \mathrm{OH}$ (3) using $\left[\mathrm{RuCp}\left(\mathrm{CH}_{3} \mathrm{CN}\right)_{3}\right] \mathrm{PF}_{6}(\mathbf{1})^{\mathrm{a}}$

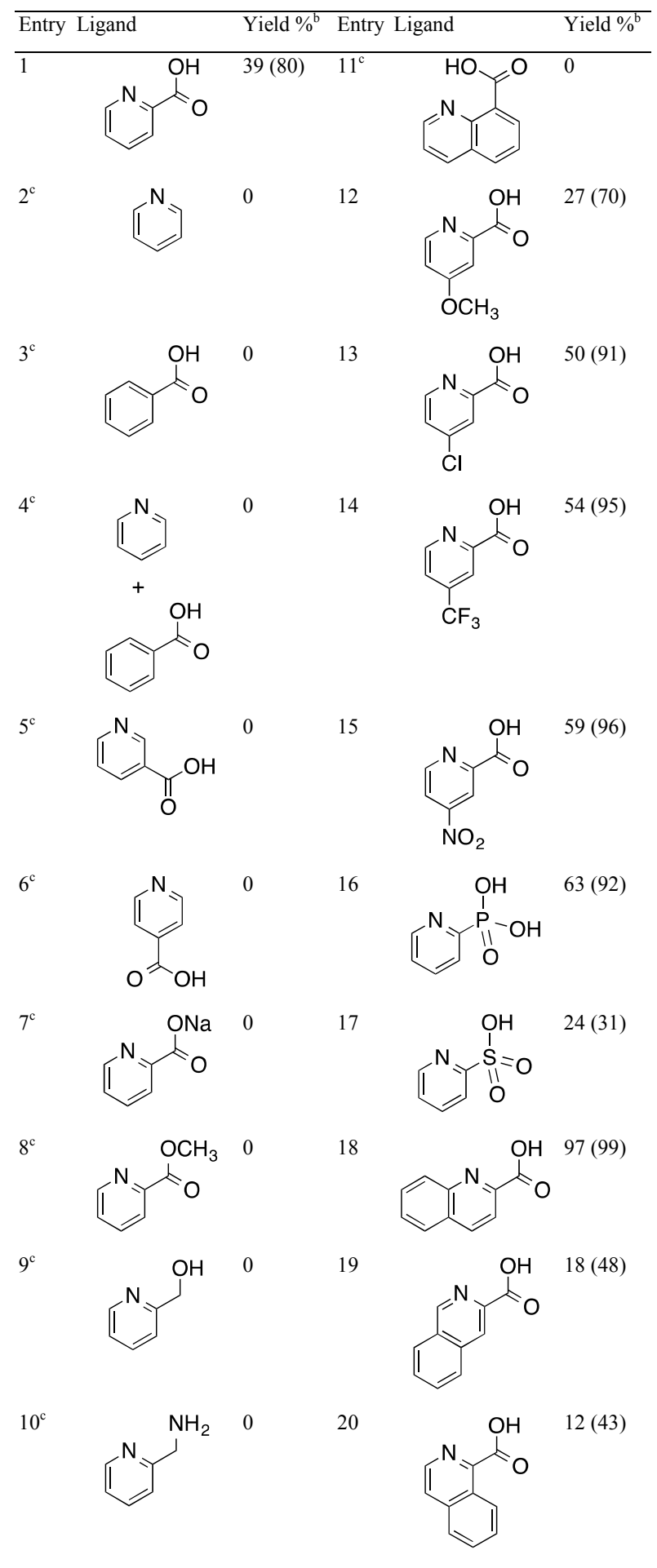

${ }^{\mathrm{a}}$ Conditions: $[2]=500 \mathrm{mM} ;[1]=[$ ligand $]=1 \mathrm{mM}$; solvent, $\mathrm{CH}_{3} \mathrm{OH}$; temperature, $30{ }^{\circ} \mathrm{C} ; 1 \mathrm{~h}$.

${ }^{\mathrm{b}}$ Values in parentheses are obtained after $3 \mathrm{~h}$.

${ }^{\mathrm{c}}[2]=100 \mathrm{mM}$.

the importance of i) a synergetic effect between the $\mathrm{sp}^{2} \mathrm{~N}$ atom and the adjacent $\mathrm{COOH}$ group, producing a five-membered chelating ring with the monocationic $\mathrm{CpRu}$ (II) catalyst precursor; 
Table 2. Optimization of deallylation conditions using $\mathrm{QAH} /\left[\mathrm{RuCp}\left(\mathrm{CH}_{3} \mathrm{CN}\right)_{3}\right] \mathrm{PF}_{6}(\mathbf{1}),\left[\mathrm{RuCp}\left({ }^{3}-\mathrm{C}_{3} \mathrm{H}_{5}\right)(\mathrm{QA})\right] \mathrm{PF}_{6}$ (5), or $\mathrm{PAH} / \mathrm{CpM}$ precursors

\begin{tabular}{|c|c|c|c|c|c|c|c|}
\hline Entry & Metal Precursor & Ligand & $1, \mathrm{mM}$ & $\mathrm{S} / \mathrm{C}$ & Solvent & Time, h & Yield $\%^{\mathrm{b}}$ \\
\hline 1 & {$\left[\mathrm{CpRu}\left(\mathrm{CH}_{3} \mathrm{CN}\right)_{3}\right] \mathrm{PF}_{6}$} & QAH & 100 & 100 & $\mathrm{CH}_{3} \mathrm{OH}$ & 0.5 & $>99$ \\
\hline 2 & {$\left[\mathrm{CpRu}\left(\mathrm{CH}_{3} \mathrm{CN}\right)_{3}\right] \mathrm{PF}_{6}$} & QAH & 500 & 500 & $\mathrm{CH}_{3} \mathrm{OH}$ & 3 & 99 \\
\hline 3 & {$\left[\mathrm{CpRu}\left(\mathrm{CH}_{3} \mathrm{CN}\right)_{3}\right] \mathrm{PF}_{6}$} & QAH & 1000 & 1000 & $\mathrm{CH}_{3} \mathrm{OH}$ & 3 & 98 \\
\hline 4 & {$\left[\mathrm{CpRu}\left({ }^{3}-\mathrm{C}_{3} \mathrm{H}_{5}\right)(\mathrm{QA})\right] \mathrm{PF}_{6}$} & - & 3000 & 10000 & $\mathrm{CH}_{3} \mathrm{OH}$ & 24 & 99 \\
\hline 5 & {$\left[\mathrm{CpRu}\left(\mathrm{CH}_{3} \mathrm{CN}\right)_{3}\right] \mathrm{PF}_{6}$} & QAH & 100 & 100 & $\mathrm{C}_{2} \mathrm{H}_{5} \mathrm{OH}$ & 2 & 99 \\
\hline 6 & {$\left[\mathrm{CpRu}\left(\mathrm{CH}_{3} \mathrm{CN}\right)_{3}\right] \mathrm{PF}_{6}$} & QAH & 100 & 100 & $i-\mathrm{C}_{3} \mathrm{H}_{7} \mathrm{OH}$ & 3 & 98 \\
\hline 7 & {$\left[\mathrm{CpRu}\left(\mathrm{CH}_{3} \mathrm{CN}\right)_{3}\right] \mathrm{PF}_{6}$} & QAH & 100 & 100 & $t-\mathrm{C}_{4} \mathrm{H}_{9} \mathrm{OH}$ & 13 & 82 \\
\hline 8 & {$\left[\mathrm{CpRu}\left(\mathrm{CH}_{3} \mathrm{CN}\right)_{3}\right] \mathrm{PF}_{6}$} & QAH & 100 & 100 & $1: 1 \mathrm{CH}_{3} \mathrm{OH}-\mathrm{H}_{2} \mathrm{O}$ & 6 & 99 \\
\hline 9 & {$\left[\mathrm{CpRu}\left(\mathrm{CH}_{3} \mathrm{CN}\right)_{3}\right] \mathrm{PF}_{6}$} & QAH & 100 & 100 & $1: 1 \mathrm{CH}_{3} \mathrm{OH}-\mathrm{DMF}$ & 6 & 99 \\
\hline 10 & {$\left[\mathrm{CpRu}\left(\mathrm{CH}_{3} \mathrm{CN}\right)_{3}\right] \mathrm{PF}_{6}$} & QAH & 100 & 100 & $1: 1 \mathrm{CH}_{3} \mathrm{OH}-\mathrm{THF}$ & 0.5 & 99 \\
\hline 11 & {$\left[\mathrm{CpRu}\left(\mathrm{CH}_{3} \mathrm{CN}\right)_{3}\right] \mathrm{PF}_{6}$} & QAH & 100 & 100 & $1: 1 \mathrm{CH}_{3} \mathrm{OH}-\mathrm{CH}_{2} \mathrm{Cl}_{2}$ & 0.5 & 99 \\
\hline 12 & {$\left[\mathrm{CpRu}\left(\mathrm{CH}_{3} \mathrm{CN}\right)_{3}\right] \mathrm{PF}_{6}$} & QAH & 100 & 100 & $1: 1 \mathrm{CH}_{3} \mathrm{OH}-\mathrm{CH}_{3} \mathrm{CN}$ & 3 & 18 \\
\hline 13 & {$\left[\mathrm{MoCp}(\mathrm{CO})_{3}\right]_{2}$} & PAH & 100 & 100 & $\mathrm{CH}_{3} \mathrm{OH}$ & 3 & 0 \\
\hline 14 & {$\left[\mathrm{WCp}(\mathrm{CO})_{3}\right]_{2}$} & PAH & 100 & 100 & $\mathrm{CH}_{3} \mathrm{OH}$ & 3 & 0 \\
\hline 15 & {$\left[\mathrm{FeCp}(\mathrm{CO})_{3}\right]_{2}$} & PAH & 100 & 100 & $\mathrm{CH}_{3} \mathrm{OH}$ & 3 & 0 \\
\hline 16 & $\mathrm{RhCp}(\operatorname{cod})$ & PAH & 100 & 100 & $\mathrm{CH}_{3} \mathrm{OH}$ & 3 & 0 \\
\hline 17 & $\operatorname{IrCp}(\operatorname{cod})$ & PAH & 100 & 100 & $\mathrm{CH}_{3} \mathrm{OH}$ & 3 & 0 \\
\hline
\end{tabular}

${ }^{a}$ Unless specified otherwise, all of reactions were carried out at $30{ }^{\circ} \mathrm{C}$.

${ }^{\mathrm{b}} \mathrm{GC}$ analysis.

Under a reduced pressure of $200 \mathrm{mmHg}$.

The pressure of the reaction system was reduced to ca. $200 \mathrm{mmHg}$ for $5 \mathrm{~min}$ every $2 \mathrm{~h}$.

ii) the acidity of the proton; and iii) the molecular orbital coefficient of the ligand (see Mechanism).

\subsection{Optimization}

Table 2 showed the results of optimization of the standard reaction $\left(\begin{array}{ll}2 & 3\end{array}\right)$ using $\mathrm{QAH}$ and $\mathbf{1}$, and other $\mathrm{Cp}$ metal precursors. The QAH/1-combined system was highly reactive, completing the reaction within 30 min (entry 1). Even with a substrate/catalyst $(\mathrm{S} / \mathrm{C})$ ratio of 500 , deprotection was achieved in $3 \mathrm{~h}$ (entry 2). Under a slightly reduced pressure $(200 \mathrm{mmHg})$, the $\mathrm{S} / \mathrm{C}$ ratio could be increased to 1000 (entry 3). Further enhancement in the reactivity was realized by using a -allyl complex, $\left[\mathrm{RuCp}\left({ }^{3}-\mathrm{C}_{3} \mathrm{H}_{5}\right)(\mathrm{QA})\right] \mathrm{PF}_{6}(5)$, which was quantitatively prepared as a pale yellow solid from 1, QAH, and allyl alcohol $(\mathrm{AllOH})$ in an exact 1:1:1 ratio (1 and $\mathrm{QAH}$, acetone, $\mathrm{rt},<5 \mathrm{~min}$; addition of $\mathrm{AllOH}, \mathrm{rt}, 15 \mathrm{~min}$; concentration of the mixture to $1 / 10$ volume). ${ }^{7 \mathrm{c}} \quad$ The complex $\mathbf{5}$ is air- and moisture-stable, which increases operational simplicity. Even with a $0.01 \mathrm{~mol} \%$ of $5(\mathrm{~S} / \mathrm{C}=10000)$, the reaction could be completed at $30{ }^{\circ} \mathrm{C}$ in $24 \mathrm{~h}$ by reducing the pressure to ca. $200 \mathrm{mmHg}$ at 2 -h intervals (entry 4). Removal of the co-product allyl methyl ether $\left(\mathrm{CH}_{3} \mathrm{OAll}\right)$ would force the equilibrium toward the desired product side. In addition to $\mathrm{CH}_{3} \mathrm{OH}, \mathrm{C}_{2} \mathrm{H}_{5} \mathrm{OH}$ and $i-\mathrm{C}_{3} \mathrm{H}_{7} \mathrm{OH}$ could be used as solvents, whereas $t-\mathrm{C}_{4} \mathrm{H}_{9} \mathrm{OH}$ gave a lower yield (entries 5-7). Reactivity was maintained in $\mathrm{CH}_{3} \mathrm{OH}$ containing $\mathrm{H}_{2} \mathrm{O}$, DMF, THF, or $\mathrm{CH}_{2} \mathrm{Cl}_{2}$ as a co-solvent. Using $\mathrm{CH}_{3} \mathrm{CN}$ as a co-solvent significantly retarded the reaction (entries 8-12). Although our investigations of the central metal were limited, $\mathrm{CpMo}, \mathrm{CpW}, \mathrm{CpFe}, \mathrm{CpRh}$, and $\mathrm{CpIr}$ precursors-which are known to form -allyl complexes-were not effective under the standard conditions using PAH (entries 13-17).
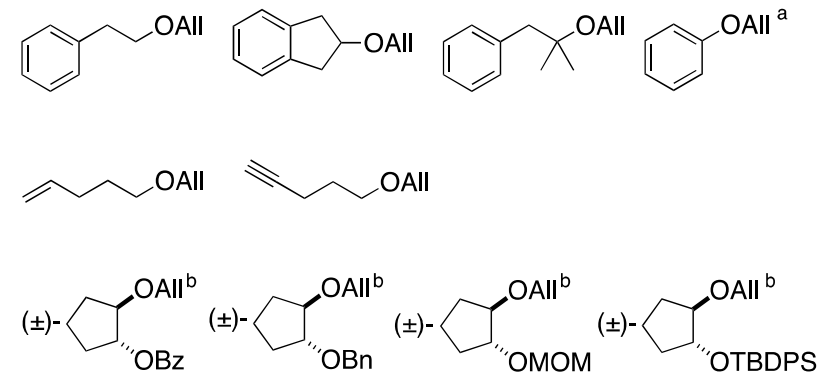

Fig. 4. Quantitative removal of allyl group from various allyl ethers at $30{ }^{\circ} \mathrm{C}$ for $3 \mathrm{~h}$ in $\mathrm{CH}_{3} \mathrm{OH}$ with $\mathrm{S} / \mathrm{C}$ ratio of 500 unless specified otherwise. ${ }^{\mathrm{a}} \mathrm{S} / \mathrm{C}=$ 100. ${ }^{\mathrm{b}} \mathrm{S} / \mathrm{C}=100$ and $0.5 \mathrm{~h} . \quad \mathrm{All}=\mathrm{CH}_{2} \mathrm{CH}=\mathrm{CH}_{2} . \quad \mathrm{Bz}=\mathrm{COC}_{6} \mathrm{H}_{5} . \mathrm{Bn}=$ $\mathrm{CH}_{2} \mathrm{C}_{6} \mathrm{H}_{5} . \mathrm{MOM}=\mathrm{CH}_{2} \mathrm{OCH}_{3} . \quad$ TBDPS $=\mathrm{Si}\left(t-\mathrm{C}_{4} \mathrm{H}_{9}\right)\left(\mathrm{C}_{6} \mathrm{H}_{5}\right)_{2}$.

\subsection{Generality}

Fig. 4 summarizes the generality of the $\mathrm{CpRu} / \mathrm{QAH}$-catalyzed deprotection of alcohols from allyl ethers. ${ }^{7 \mathrm{a}-7 \mathrm{c}}$ Primary, secondary, and tertiary alkanols, and phenol were quantitatively deprotected. No Claisen rearrangement occurred with allyl phenyl ether. Both allyl 4-pentenyl ether and allyl 4-pentynyl ether were quantitatively converted to the corresponding alcohol without, respectively, isomerization of the terminal olefin to an internal olefin or inhibition from the terminally alkyne. Benzoate, benzyl ether, methoxymethyl ether, and tert-butyldiphenylsilyl ether were not affected at all, realizing selective removal of allyl group.

As shown in Fig. 5, the present catalytic allyloxy bond cleaver could be used for allyl esters including carbonates, carboxylates, and phosphates. ${ }^{7 \mathrm{e}}$ Allyloxycarbonyl (AOC)-protected alcohols showed much higher reactivity than other esters: a turnover number of one million was attained by continuous removal of 
a allyl carbonate $([\mathrm{sub}]=500 \mathrm{mM})$

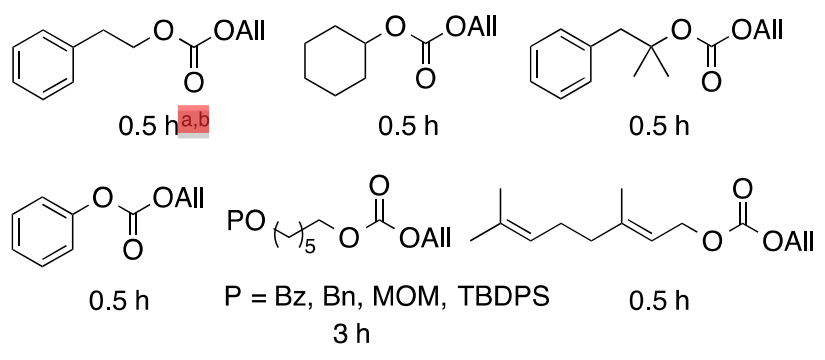

b allyl carboxylate $([\mathrm{sub}]=100 \mathrm{mM})$<smiles>O=C(CCc1ccccc1)O[Na]</smiles><smiles>O=C(O)C1CCCCC1</smiles><smiles>COC(=O)C(C)(C)C</smiles>

$20 \mathrm{hc}$

$9 \mathrm{~h}$

$18 \mathrm{~h}$<smiles>O=C(O)c1ccccc1</smiles><smiles>C=CCCCC(=O)O[Na]</smiles><smiles></smiles>

c allyl carbamate $([\mathrm{sub}]=[\mathrm{TfOH}]=100 \mathrm{mM})^{\mathrm{e}}$<smiles>O=C(NCc1ccccc1)O[Na]</smiles>

$1 \mathrm{~h}$<smiles>O=C(Nc1ccccc1)O[Na]</smiles>

$1 h^{f}$<smiles>COC(=O)NC1CCCCC1</smiles>

$2 \mathrm{~h}$<smiles>O=C(O)N1CCOCC1</smiles>

$1 \mathrm{~h}$<smiles>COC(=O)NC(C)(C)Cc1ccccc1</smiles>

$0.5 \mathrm{~h}$

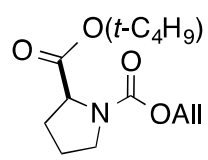

$6 \mathrm{~h}$
Fig. 5. Quantitative removal of allyl group from various allyl esters at 30 ${ }^{\circ} \mathrm{C}$ in $\mathrm{CH}_{3} \mathrm{OH}$ with $\mathrm{S} / \mathrm{C}$ ratio of 500 unless specified otherwise. The value is the reaction time. ${ }^{1} 10-\mathrm{g}$ scale. ${ }^{7 \mathrm{C}} 9$ days with $\mathrm{S} / \mathrm{C}$ ratio of $1.0 \times 10^{6}$. $\mid \mathrm{iPrOH}$ instead of $\mathrm{CH}_{3} \mathrm{OH}$. $\$ 500 \mathrm{mM}$. $\mathrm{S} / \mathrm{C}=100$. $\mid 88 \%$ yield.

volatile $\mathrm{CH}_{3} \mathrm{OAll}$. For diallyl carbonates, only less substituted allyl groups were selectively removed. Amines protected as an $\mathrm{N}$-AOC group were efficiently deprotected in the presence of a 1mol amount of $\mathrm{CF}_{3} \mathrm{SO}_{3} \mathrm{H}$ to give the corresponding ammonium salt without any $\mathrm{N}$-allylated side product. ${ }^{7 \mathrm{~d}}$ The effectiveness of isolation could be amplified by salt formation. A 1-mol amount of Nafion ( $\mathrm{SO}_{3} \mathrm{H}$ equivalent), $\mathrm{CH}_{3} \mathrm{SO}_{3} \mathrm{H}$, and $12 \mathrm{M}$ aqueous $\mathrm{HCl}$ could be used, whereas a 10 -mol amount of $\mathrm{CH}_{3} \mathrm{COOH}$ was required for efficient cleavage.

The "No additive-One step" allyl cleaver functions smoothly without requiring an excess amount of reducing reagents, acids, bases, or oxidizing reagents, which often complicate the process of isolating the products. Therefore, the $\mathrm{CpRu} / \mathrm{QAH}$-combined catalyst can be applied to peptide synthesis and to the final deprotection stage in the synthesis of polar biomolecular compounds. Some examples are shown in Fig. 6. Highly multifunctionalized molecules, such as $N$-Fmoc-( $S)-\mathrm{Glu}(\mathrm{OAll})-\mathrm{O} t \mathrm{Bu}$, $N$-Fmoc-( $S$ )-Phe-( $S$ )-Glu(OAll)-O $t \mathrm{Bu}, \quad N$-Fmoc- $(S)$-Ser(OAll)$(S)$-Phe-O $t \mathrm{Bu}, 2$ '-OAll uridine, $N$-AOC- $(S)$-Pro-O $t$ Bu, and $N$ AOC- $(S)$-Pro- $(S)$-Pro-Gly-O $t$ Bu, were quantitatively deallylated without affecting the $t \mathrm{Bu}$ ester or Fmoc groups and without loss of reactivity, even in the presence of a highly coordinative peptide linkage. .a,7d,7e An RNA-related molecule-fully allylprotected 3,5-U-was also converted in one step to 3,5-U, which was then isolated after $\left(\mathrm{C}_{2} \mathrm{H}_{5}\right)_{3} \mathrm{~N}$ addition. ${ }^{7 \mathrm{f}}$ After the

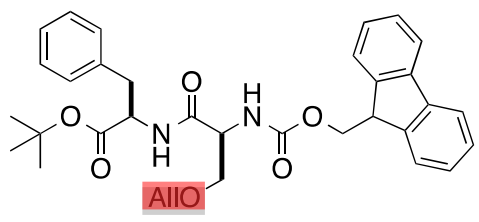

$>99 \%$ yield

$\mathrm{S} / \mathrm{C}, 100$

time, $4 \mathrm{~h}$

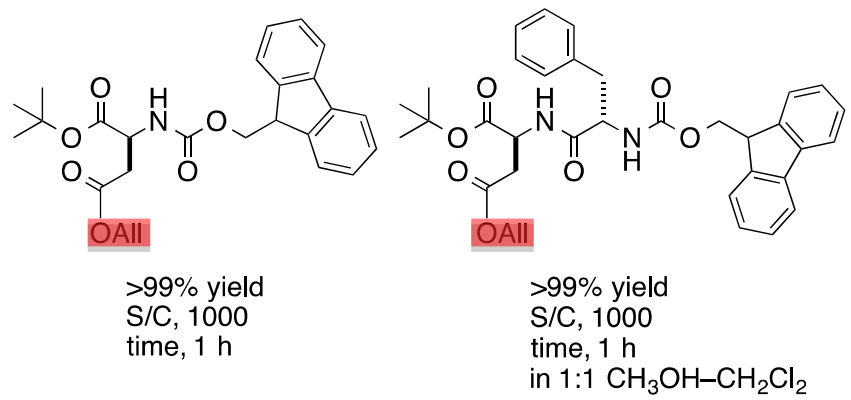<smiles>CCCC1CCCCC1C(=O)NCC(=O)OC(C)(C)C</smiles>

$>99 \%$ yield $\mathrm{S} / \mathrm{C}, 100$ time, $2 \mathrm{~h}$

$>99 \%$ yield $\mathrm{S} / \mathrm{C}, 100$ time, $2 \mathrm{~h}$

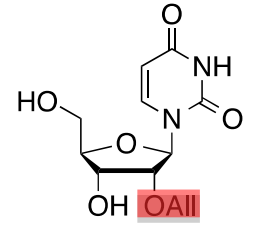

$>99 \%$ yield $\mathrm{S} / \mathrm{C}, 100$ time, $4 \mathrm{~h}$

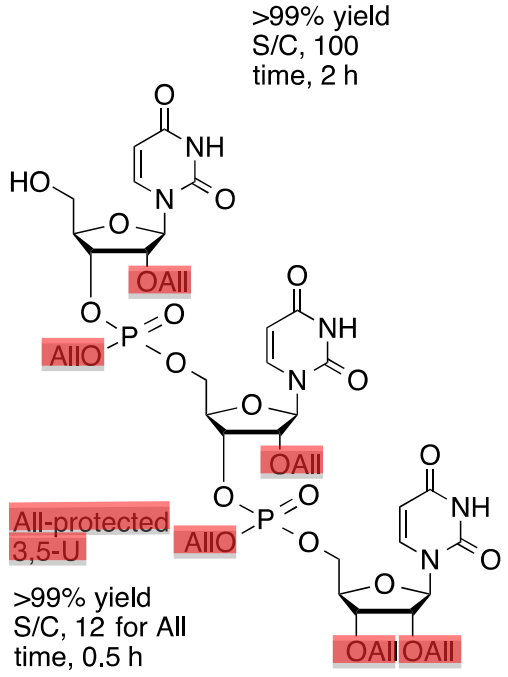

Fig. 6. Application to highly polar molecules. The deprotection yield as well as the conditions are shown below the substrate structure.

deprotection process, a catalyst sometimes ends up as an impurity in the final product. In this regard, a homogeneous catalyst is disadvantageous in comparison to its heterogeneous counterpart. The heterogeneous deallylation catalyst 6 immobilized on microsize spherical $\mathrm{SiO}_{2}$ particles containing $\mathrm{Fe}_{3} \mathrm{O}_{4}$ should be all the more practical because it can operate in alcoholic solvents in the absence of extra additives and the only co-product is volatile $\mathrm{CH}_{3} \mathrm{OAll}$. Products can be easily isolated through a simple deprotection step, followed by magnetic separation of $\mathbf{6}$, and an evaporation process. 3,5-U was successfully deprotected by using the heterogeneous version of the catalyst. ${ }^{7 \mathrm{~h}}$

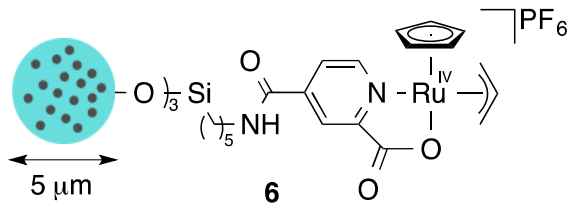




\subsection{Mechanism}

\subsubsection{NMR study and kinetics}

Fig. 7 shows the step-by-step changes in the ${ }^{1} \mathrm{H}-\mathrm{NMR}$ spectrum during the reaction of QAH, $\left[\mathrm{RuCp}\left(\mathrm{CH}_{3} \mathrm{CN}\right)_{3}\right] \mathrm{PF}_{6}(\mathbf{1})$, $\mathrm{CH}_{2}=\mathrm{CHCH}_{2} \mathrm{OH}(\mathrm{AllOH}), \mathrm{C}_{6} \mathrm{H}_{5} \mathrm{CH}_{2} \mathrm{CH}_{2} \mathrm{OAll}$ (2), and $\mathrm{CH}_{3} \mathrm{OH}$ in acetone- $d_{6}$ at $30{ }^{\circ} \mathrm{C}$. When a 1-mol amount of 1 was added to a solution of QAH, the six aromatic proton signals of QAH completely and immediately disappeared to generate two new sets of relatively broad signals in a 20:1 ratio (Fig. 7a and $7 \mathbf{b}$ ). The major set could be plausibly assigned to $[\mathrm{RuCp}(\mathrm{QAH}) \mathrm{S}] \mathrm{PF}_{6}$ (7, $\mathrm{S}=\mathrm{CH}_{3} \mathrm{CN}$ or $\left.\left(\mathrm{CD}_{3}\right)_{2} \mathrm{CO}\right)$, while the minor one might be due to a species equilibrating with 7-for example, [RuCp(QA)S] (8) $/ \mathrm{HPF}_{6}$ or a $\mathrm{COOH}$-dangling complex 9 (for supposed structures, see Fig. 11).

Consistent with such a dynamic system, both the major and minor signals were converted to a single set of sharp signals when a 1-mol amount of $\mathbf{2}$ was introduced (Fig. 7c). The new signals could be definitely assigned to the -allyl complex $\left[\mathrm{RuCp}\left({ }^{3}-\mathrm{C}_{3} \mathrm{H}_{5}\right)(\mathrm{QA})\right] \mathrm{PF}_{6}(5)$, in which the -allyl ligand takes an endo conformation to $\mathrm{Cp}$, as supported by the observation of $2 \%$ and $4.5 \%$ nOe enhancement between the closely located $\mathrm{CpH}$ and the anti-protons $\mathrm{H}_{\mathrm{A}}$ and $\mathrm{H}_{\mathrm{A}^{\prime}}$ of the -allyl group. ${ }^{7 \mathrm{~b}}$ The

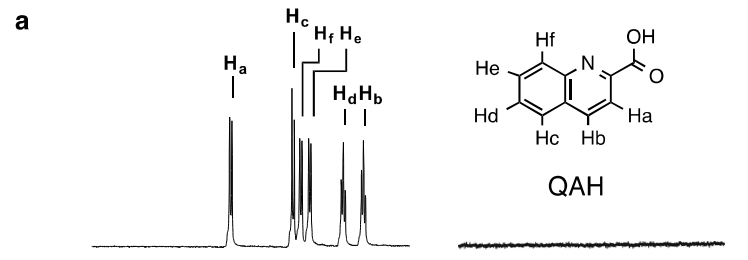

b

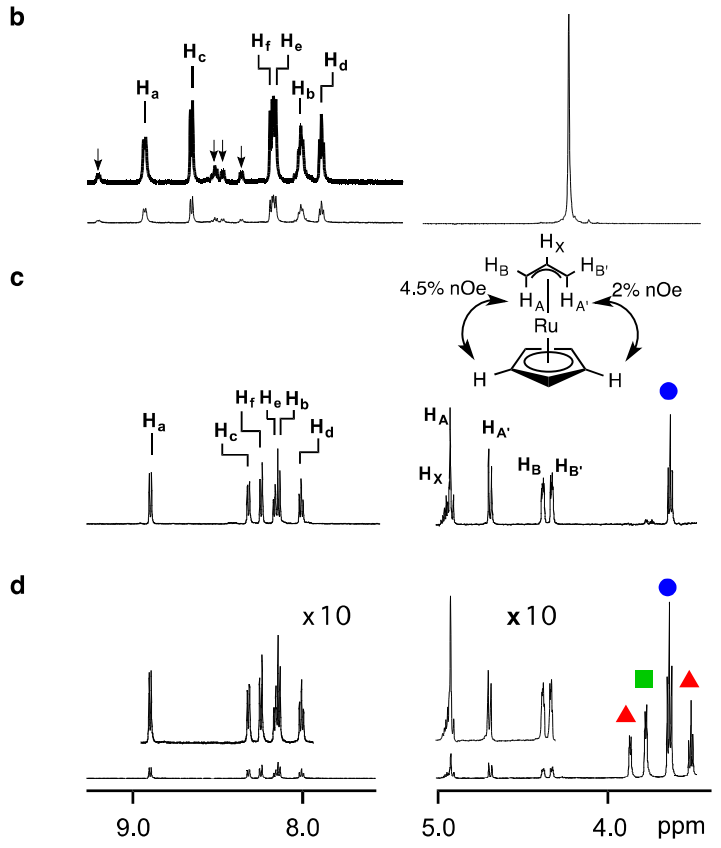

Fig. 7. ${ }^{1} \mathrm{H}-\mathrm{NMR}$ behavior in the reaction of $\mathrm{QAH}$ with [RuCp $\left(\mathrm{CH}_{3} \mathrm{CN}_{3}\right] \mathrm{PF}_{6}(\mathbf{1}), \mathrm{C}_{6} \mathrm{H}_{5} \mathrm{CH}_{2} \mathrm{CH}_{2} \mathrm{OAll}$ (2), and $\mathrm{CH}_{3} \mathrm{OH}$ (acetone- $d_{6}$, $\left.30^{\circ} \mathrm{C}\right)$. (a) Quinaldic acid (QAH) $(10 \mathrm{mM})$. (b) $10 \mathrm{~min}$ after addition of 1 mol amount of 1. (c) $30 \mathrm{~min}$ after addition of $1 \mathrm{~mol}$ amount of $\mathbf{2}$. The structure of QA moiety in the spectrum is omitted. (d) $12 \mathrm{~h}$ after addition of 10 mol amounts of 2 and 100 mol amounts of $\mathrm{CH}_{3} \mathrm{OH}$. Blue sphere: $\mathrm{C}_{6} \mathrm{H}_{5} \mathrm{CH}_{2} \mathrm{CH}_{2} \mathrm{OH}$ (3). Red triangle: $\mathrm{C}_{6} \mathrm{H}_{5} \mathrm{CH}_{2} \mathrm{CH}_{2} \mathrm{OAll}$ (2). Green square: $\mathrm{CH}_{3} \mathrm{OAll}$. All $=\mathrm{CH}_{2} \mathrm{CH}=\mathrm{CH}_{2}$. The factor of $\mathrm{OCH}_{2}$ signal intensity of $\mathrm{CH}_{3} \mathrm{OAll}$ for 2 was ca. 0.5 .
$\mathrm{A}_{2} \mathrm{~B}_{2} \mathrm{X}$ signal pattern of the -allyl ligand, rather than $\mathrm{A}_{4} \mathrm{X}$, indicates that the - - exchange in 5 is slow on the ${ }^{1} \mathrm{H}$ NMR timescale. Stereoselective generation of endo-5 can be explained by attractive interactions between -allyl 1,3-p orbitals and $\mathrm{Ru}$ $\mathrm{d}_{\mathrm{xy}} *$ and between -allyl 2-p* orbital and $\mathrm{Ru} \mathrm{d}_{\mathrm{z2}}$.

The spectrum was not changed by the addition of a 1-mol amount of $\mathrm{C}_{6} \mathrm{H}_{5} \mathrm{CH}_{2} \mathrm{CH}_{2} \mathrm{OAll}$ (2) into the solution of $\mathbf{5}$. When 10-mol amounts of 2 and 100-mol amounts of $\mathrm{CH}_{3} \mathrm{OH}$ were added to $\mathbf{5}, 70 \%$ of 2 was consumed after $12 \mathrm{~h}$ at $30{ }^{\circ} \mathrm{C}$ to generate $\mathrm{C}_{6} \mathrm{H}_{5} \mathrm{CH}_{2} \mathrm{CH}_{2} \mathrm{OH}(3)$ and $\mathrm{CH}_{3} \mathrm{OAll}$ in a $1: 1$ ratio (Fig. 7d). Here, only the -allyl complex 5 was observed, showing i) that a -allyl mechanism is operating; ii) that $\mathbf{5}$ is in the resting state of the catalytic cycle; and iii) that the rate is determined at the reductive nucleophilic attack of $\mathrm{CH}_{3} \mathrm{OH}$ on the -allyl $\mathrm{C}(1)$ or $\mathrm{C}(3)$ of 5 (see section 2.5.4).

The ${ }^{1} \mathrm{H}-\mathrm{NMR}$ behavior agreed well with the kinetics shown in Fig. 8: the reaction proceeded with a 0th-order dependence on the initial concentration of $\mathrm{C}_{6} \mathrm{H}_{5} \mathrm{CH}_{2} \mathrm{CH}_{2} \mathrm{OAll}$ (2) and with a 1storder dependence on the initial concentration of the $\mathrm{Ru}$ complex 5 during the early stage of $0 \%-30 \%$ conversion of $2 .{ }^{15}$ Because both 2 and $\mathrm{CH}_{3} \mathrm{OAll}$ act as an allyl donor, an excess amount of $\mathrm{CH}_{3} \mathrm{OH}$ forced the equilibrium $\mathbf{2}+\mathrm{CH}_{3} \mathrm{OH} \leftrightarrows \mathbf{3}+\mathrm{CH}_{3} \mathrm{OAll}$ far to the right side. The 0.25:0.788:0.688:9.31 ratio of $\mathbf{2}, \mathbf{3}, \mathrm{CH}_{3} \mathrm{OAll}$, and $\mathrm{CH}_{3} \mathrm{OH}$ observed in the ${ }^{1} \mathrm{H}-\mathrm{NMR}$ spectrum (Fig. 7d) determined an equilibrium constant $K$ of ca. 0.23 , indicating that the $\mathbf{2}+\mathrm{CH}_{3} \mathrm{OH}$ side is preferred over the $\mathbf{3}+\mathrm{CH}_{3} \mathrm{OAll}$ side under the reaction conditions.
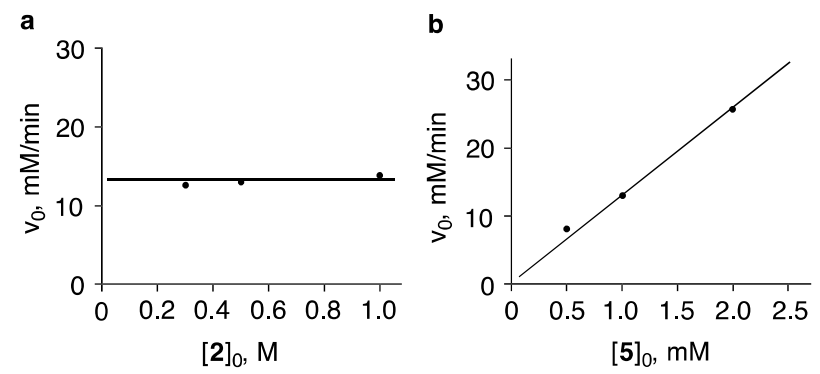

Fig. 8. Dependence of the initial rate $v_{0}(\mathrm{mM} / \mathrm{min})$ on $\left[\mathrm{C}_{6} \mathrm{H}_{5} \mathrm{CH}_{2} \mathrm{CH}_{2} \mathrm{OAll}\right.$ (2) $]_{0}$ and $\left[\left[\mathrm{RuCp}\left({ }^{3}-\mathrm{C}_{3} \mathrm{H}_{5}\right)(\mathrm{QA})\right] \mathrm{PF}_{6}(\mathbf{5})\right]_{0}$ in the deallylation of $\mathbf{2}$ in $\mathrm{CD}_{3} \mathrm{OD}$ at $30{ }^{\circ} \mathrm{C}$. (a) Plot of $v_{0}$ as a function of $[2]_{0}$ from $300 \mathrm{mM}$ to $1000 \mathrm{mM}\left([\mathbf{5}]_{0}=\right.$ $1.00 \mathrm{mM}$ ). (b) Plot of $v_{0}$ as a function of [5 $]_{0}$ from $0.500 \mathrm{mM}$ to $2.00 \mathrm{mM}$ $\left([2]_{0}=500 \mathrm{mM}\right)$.

\subsubsection{X-ray crystallographic analysis}

The -allyl complex 5 was air- and moisture-stable and easily crystalized from dichloromethane (yellow, prism, mp $166{ }^{\circ} \mathrm{C}$ $(\mathrm{dec})) .^{7 \mathrm{~b}}$ A series of -allyl $\mathrm{Ru}$ complexes of 4 -X-substituted picolinate (4-X-PA, where $\mathrm{X}=\mathrm{CH}_{3} \mathrm{O}, \mathrm{H}, \mathrm{Cl}, \mathrm{CF}_{3}$, and $\mathrm{NO}_{2}$ ) were prepared, and the molecular structures in the crystalline state are shown in Fig. 9. In all cases, the -allyl ligand had a conformation that was endo to the $\mathrm{Cp}$ group, being consistent with the structure of 5 in solution. The -allyl C(3)-Ru bond was ca. 5\% longer than the $\mathrm{C}(1)-\mathrm{Ru}$ bond, albeit with a few exceptions. This observation indicates that the rate-determining reductive nucleophilic attack of $\mathrm{CH}_{3} \mathrm{OH}$ may occur on the $\mathrm{C}(3)$ carbon.

\subsubsection{Hammett plots and molecular orbital analysis}

The relative reactivity of $\mathrm{PAH}$ for $4-\mathrm{X}-\mathrm{PAH}\left(\mathrm{X}=\mathrm{CH}_{3} \mathrm{O}, \mathrm{Cl}\right.$, $\mathrm{CF}_{3}$, and $\mathrm{NO}_{2}$ ) was investigated in the Ru-catalyzed deallylation of 2 to 3 under the conditions of [4-X-PAH] = [1] = $1 \mathrm{mM}$; [2] = $500 \mathrm{mM} ; \mathrm{CH}_{3} \mathrm{OH} ; 30{ }^{\circ} \mathrm{C}$ ). As shown in Fig. 10a, a stronger electron-withdrawing ability of $\mathrm{X}$ led to higher reactivity, but the 


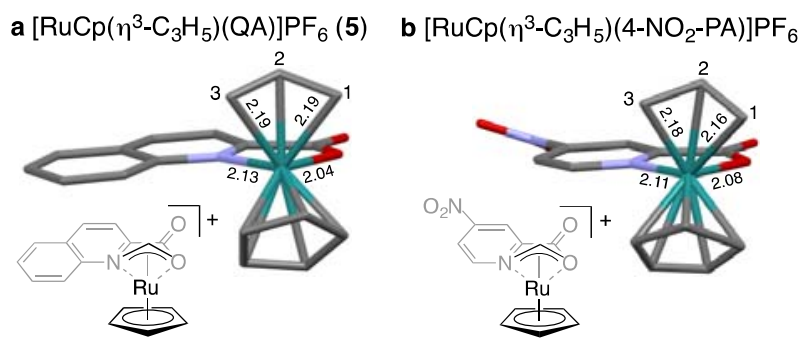

c $\left[\mathrm{RuCp}\left(\eta^{3}-\mathrm{C}_{3} \mathrm{H}_{5}\right)(4-\mathrm{Cl}-\mathrm{PA})\right] \mathrm{PF} \mathrm{F}_{6}$ d $\left[\mathrm{RuCp}\left(\eta^{3}-\mathrm{C}_{3} \mathrm{H}_{5}\right)\left(4-\mathrm{CF}_{3}-\mathrm{PA}\right)\right] \mathrm{PF} \mathrm{F}_{6}$
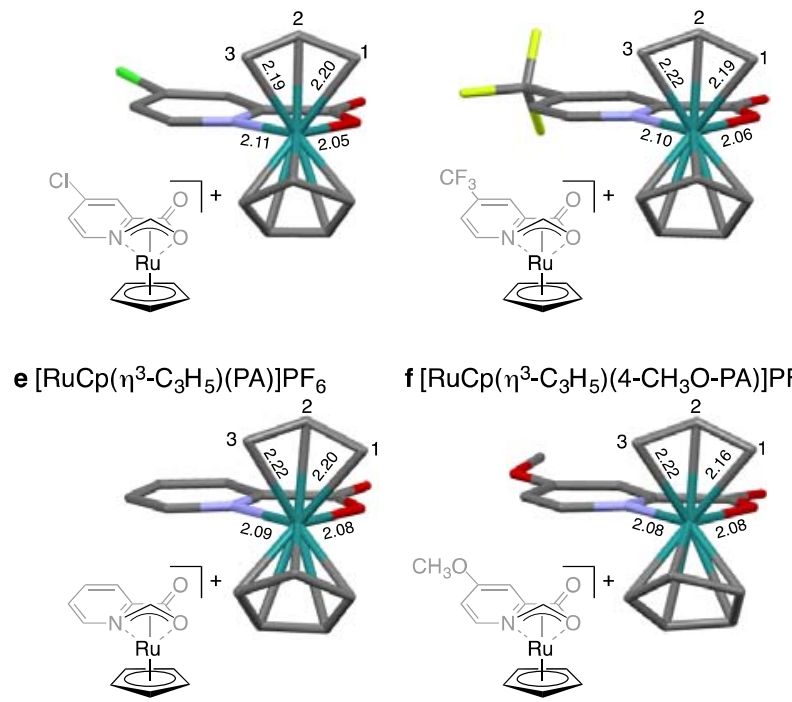

Fig. 9. Molecular structures of $\left[\mathrm{RuCp}\left({ }^{3}-\mathrm{C}_{3} \mathrm{H}_{5}\right)(\mathrm{QA})\right] \mathrm{PF}_{6}$ (a) and $\left[\mathrm{RuCp}\left({ }^{3}\right.\right.$ $\left.\left.\mathrm{C}_{3} \mathrm{H}_{5}\right)(4-\mathrm{X}-\mathrm{PA})\right] \mathrm{PF}_{6}(\mathbf{b}-\mathbf{f})$ in the crystalline state. QAH: quinaldic acid. 4-XPAH: 4-X-substituted picolinic acid.

degree of rate enhancement was not as significant as expected: $0.7\left(\mathrm{CH}_{3} \mathrm{O},-0.28\right.$ ( value) $), 1(\mathrm{H}, 0.00), 1.4(\mathrm{Cl}, 0.22), 1.6\left(\mathrm{CF}_{3}\right.$, $0.53)$, and $1.9\left(\mathrm{NO}_{2}, 0.81\right)$. Hammett plots of $\log \left(k_{\mathrm{X}} / k_{\mathrm{H}}\right)$ versus the standard constant for the substituent parameter exhibited two linear free-energy relationships with a value of +0.63 for $\mathrm{X}$ $=\mathrm{CH}_{3} \mathrm{O}, \mathrm{H}$, and $\mathrm{Cl}$, and +0.20 for $\mathrm{X}=\mathrm{Cl}, \mathrm{CF}_{3}$, and $\mathrm{NO}_{2}$, respectively. The two-line behavior may be rationalized by the balance between two factors: i) the -accepting ability of the pyridine moiety, and ii) the acidity of the carboxylic acid of 4-X$\mathrm{PAH}^{17}$ In the rate-determining reductive nucleophilic attack of $\mathrm{CH}_{3} \mathrm{OH}$ on the -allyl ligand of $\left[\mathrm{Ru}(\mathrm{IV}) \mathrm{Cp}\left({ }^{3}-\mathrm{C}_{3} \mathrm{H}_{5}\right)(4-\mathrm{X}-\right.$ $\mathrm{PA}) \mathrm{PF}_{6}$, a ligand with higher -acceptability and a lower lowest unoccupied molecular orbital (LUMO) level should stabilize the transition state. This view is consistent with the LUMO level/reactivity relationship shown in Fig. 10b, and holds even after taking the atomic orbital coefficient (AtOrCo) of the nitrogen atom into consideration. As the AtOrCo/LUMO value decreases, the reactivity increases. -Expanded QAH, which has a LUMO level $0.6 \mathrm{eV}$ lower than that of PAH (2.12 vs 1.52), shows a reactivity that is $5-10$-fold higher than PAH. At the same time, however, a strong electron-withdrawing group with a high value raises the acidity of $\mathrm{COOH}$. The dibasic mono salt $[\mathrm{Ru}(\mathrm{II}) \mathrm{Cp}(4-\mathrm{X}-\mathrm{PAH})] \mathrm{PF}_{6}$ may exist in equilibrium with the neutral complex $[\mathrm{Ru}(\mathrm{II}) \mathrm{Cp}(4-\mathrm{X}-\mathrm{PA})]$ and $\mathrm{HPF}_{6}$. The acidity of $\mathrm{COOH}$ in $[\mathrm{Ru}(\mathrm{II}) \mathrm{Cp}(4-\mathrm{X}-\mathrm{PAH})] \mathrm{PF}_{6}$ would be enhanced by coordination of the $\mathrm{COOH}$ oxygen atom to the mono cationic central $\mathrm{Ru}$ atom, intensifying the acidity of $\mathrm{COOH}$ beyond expectation from the general $\mathrm{pKa}$ values of $\mathrm{PAH}$ (ca. 5.4) and $\mathrm{HPF}_{6}$ (ca. -20). An increase in the generation of neutral species a

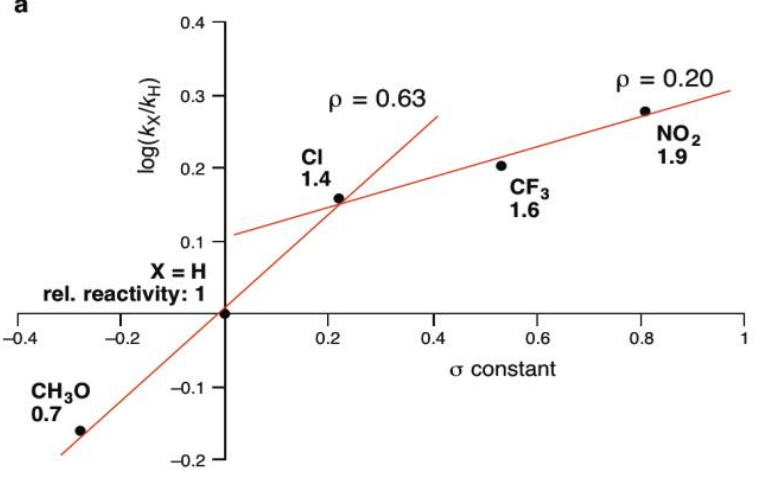

b

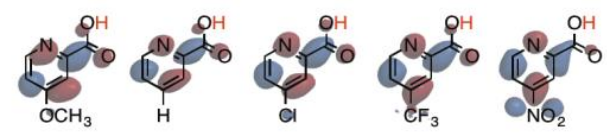

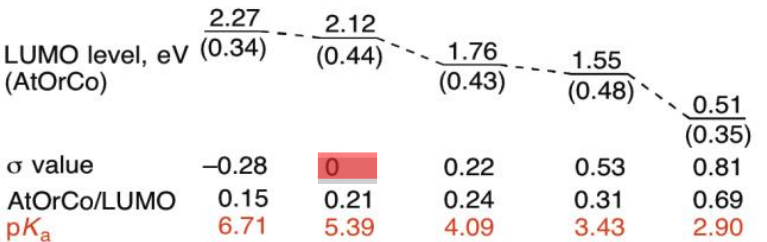

Fig. 10. Relationship between reactivity, LUMO energy level and acidity of 4-X-substituted picolinic acid (4-X-PAH) in deallylation of $\mathrm{C}_{6} \mathrm{H}_{5} \mathrm{CH}_{2} \mathrm{CH}_{2} \mathrm{OAll}$ (2) to $\mathrm{C}_{6} \mathrm{H}_{5} \mathrm{CH}_{2} \mathrm{CH}_{2} \mathrm{OH}$ (3) under the conditions of [2] = $500 \mathrm{mM} ;\left[\left[\mathrm{RuCp}\left(\mathrm{CH}_{3} \mathrm{CN}\right)_{3}\right] \mathrm{PF}_{6}(\mathbf{1})\right]=[4-\mathrm{X}-\mathrm{PAH}]=1 \mathrm{mM} ; \mathrm{CH}_{3} \mathrm{OH} ; 30{ }^{\circ} \mathrm{C}$. All $=\mathrm{CH}_{2} \mathrm{CH}=\mathrm{CH}_{2}$. (a) Hammett plots of relative reactivity $\left(\log \left(k_{\mathrm{X}} / k_{\mathrm{H}}\right)\right.$ as a function of standard constants. (b) LUMO energy calculated at a $6-31 \mathrm{G}^{*}$ level, AtOrCo (atomic orbital coefficiency on $\mathrm{N}$ ), and $\mathrm{p} K_{\mathrm{a}}(\mathrm{COOH})$ of $4-\mathrm{X}$ PAH.

with no Intramol-RDACat ability is likely to lower the catalyst performance of the $\mathrm{CpRu}(\mathrm{II})^{+} / \mathrm{Br} ø$ nsted acid-combined system. This would explain our observation that replacement of $\mathrm{COOH}$ in $\mathrm{PAH}$ with highly acidic $\mathrm{SO}_{3} \mathrm{H}$ led to low reactivity (Table $\mathbf{1}$, entry 17$)$.

\subsubsection{Supposed catalytic cycle}

On the basis of the results of the NMR study, kinetics experiments, structural analysis of Ru -allyl complexes by Xray diffraction, Hammett plots analysis, and molecular orbital calculation, the catalytic cycle of the present deallylation using the $\left[\mathrm{RuCp}\left(\mathrm{CH}_{3} \mathrm{CN}\right)_{3}\right] \mathrm{PF}_{6} \quad(\mathbf{1}) / \mathrm{QAH}$-combined system or $\left[\mathrm{RuCp}\left({ }^{3}-\mathrm{C}_{3} \mathrm{H}_{5}\right)(\mathrm{QA})\right] \mathrm{PF}_{6}(\mathbf{5})$ was deduced, as shown in Fig. 11. First of all, $\mathrm{CH}_{3} \mathrm{CN}$ in $\mathbf{1}$ is easily replaced with QAH to generate a mono cationic complex $\left[\mathrm{RuCp}(\mathrm{QAH}) \mathrm{S}_{\mathrm{PF}} \mathrm{PF}_{6}(7)\right.$, which is in equilibrium with both a neutral complex $[\mathrm{RuCp}(\mathrm{QA}) \mathrm{S}](\mathbf{8}) / \mathrm{HPF}_{6}$ and a $\mathrm{COOH}$-dangling species $\left[\mathrm{RuCp}(\mathrm{QAH}) \mathrm{S}_{2}\right] \mathrm{PF}_{6}($ (9). The $\mathrm{Ru}(\mathrm{II})^{+} / \mathrm{H}^{+}$in $[\mathrm{RuCp}(\mathrm{QAH}) \mathrm{S}] \mathrm{PF}_{6}$ captures an allyl ether substrate, $\mathrm{CH}_{2}=\mathrm{CHCH}_{2} \mathrm{OR}$, to form the catalyst/substrate complex 10, in which the hard ether $\mathrm{O}$ atom interacts with the hard $\mathrm{H}^{+}$ion, and the soft olefin double bond interacts with the soft $\mathrm{Ru}$ atom. The hydrogen bond in $\mathbf{1 0}$ enhances the electrophilicity of $\mathrm{C}(3)$ and $\mathrm{C}(1)$ in $\mathrm{CH}_{2}=\mathrm{CHCH}_{2} \mathrm{OR}$, while the electron donicity or nucleophilicity of the central $\mathrm{Ru}$ atom is amplified by coordination of the carboxylate-like $\mathrm{O}$ atom, electron-donative $\mathrm{sp}^{2} \mathrm{~N}$ atom, and mono anionic ${ }^{5} \mathrm{Cp}$ ligand. This synergetic effect realizes a charge alternation in $\mathrm{H}--\mathrm{O}-\mathrm{C}(1)-$ $\mathrm{C}(2)=\mathrm{C}(3)--\mathrm{Ru}-\mathrm{OCO}$ to reduce the energy level of the transition state. The Intramol-RDACat ability facilitates the oxidative formation of the endo- -allyl complex 5, liberating a deprotected alcohol. The rate-determining reductive nucleophilic attack of 
$\mathrm{CH}_{3} \mathrm{OH}$ on the -allyl carbon is made easier by the lower LUMO energy of QAH, generating 11. The $\mathrm{CH}_{3} \mathrm{OAll}$ is then replaced with the substrate $\mathbf{2}$, thereby completing the cycle. All elementary steps are reversible, but the presence of an excess amount of $\mathrm{CH}_{3} \mathrm{OH}$ solvent rotates the cycle in a clockwise way. Removal of the volatile co-product by reducing the internal pressure or by purging the reaction mixture with an inert gas would result in an infinite turnover number.

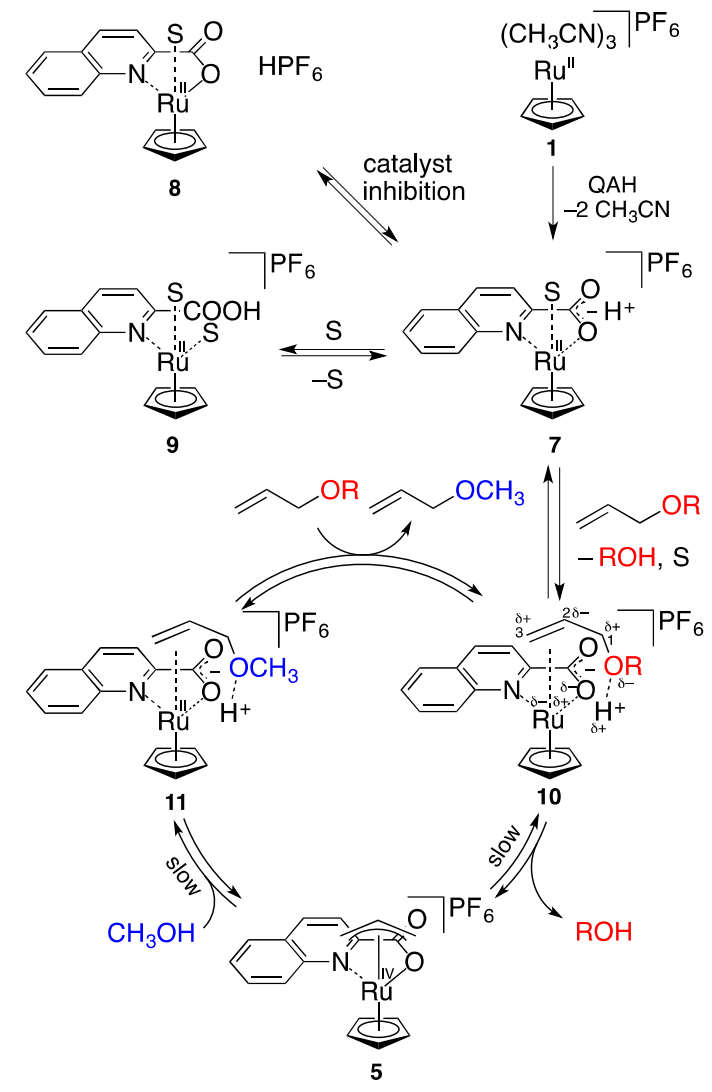

Fig. 11. Supposed catalytic cycle in deprotection of alcohols using $\mathrm{CpRu}^{+} / \mathrm{QAH}$-combined system. $\mathrm{S}=\mathrm{CH}_{3} \mathrm{CN}, \mathrm{CH}_{3} \mathrm{OH}$, substrate, product, etc.

\section{Conclusion}

In summary, the $\mathrm{CpRuPF}_{6}$-quinaldic acid catalyst described here functions as a highly reactive and chemoselective allyloxy bond cleaver in alcoholic solvents under very mild and essentially additive-free conditions. The only co-product is volatile ether. The efficiency and simplicity of the reaction should further increase the practical utility of allyl groups for the protection of alcohols, esters, and amines, among many other protecting groups in organic synthesis. Furthermore, the validity of our leading concept for designing the molecular catalystnamely "soft transition metal/hard Brønsted acid-combined catalyst" or "redox-mediated donor-accepter bifunctional catalyst (RDACat)" - has been confirmed by a series of experiments including i) ${ }^{1} \mathrm{H}-\mathrm{NMR}$ spectrometry; ii) X-ray crystallographic analyses of $\mathrm{CpRu}$ - -allyl complexes of picolinic acid derivatives; iii) Hammett plot analysis; and iv) the relationship between LUMO levels of ligands and reactivity. The present study should stimulate further ideas, not only for the retrosynthetic design of pharmaceutically important natural and unnatural compounds, but also for the continued development of molecular catalysis. ${ }^{18}$

\section{Experimental}

\subsection{General}

A Chemspeed ASW2000 system was used to screen ligands. Nuclear magnetic resonance (NMR) spectra were recorded on a JEOL JNM-ECA-600 spectrometer. Chemical shifts are expressed in parts per million (ppm) downfield from tetramethylsilane or in ppm relative to $\mathrm{CHCl}_{3}$ and $\mathrm{CHD}_{2} \mathrm{COCD}_{3}$ ( 7.26 and 2.05 in ${ }^{1} \mathrm{H}$ NMR, and 77.0 and 29.8 in ${ }^{13} \mathrm{C} \mathrm{NMR}$ ). The signal patterns of ${ }^{1} \mathrm{H}$ NMR are indicated as follows: $\mathrm{s}$, singlet; d, doublet; t, triplet; q, quartet; $\mathrm{m}$, multiplet; and br, broad signal. X-ray crystallographic analysis was conducted on a Rigaku Saturn 70 CCD system, and the structure was solved by direct methods using CrystalStructure crystallographic software. Quantum chemical calculations were performed using the Spartan 10 program implemented on an Apple iMac $3.4 \mathrm{GHz}$ intel core i7. Gas chromatography analyses were performed on a Shimadzu GC-17A instrument. Argon (Ar) gas was purified by passage first through a column of BASF R3-11 catalyst at $80{ }^{\circ} \mathrm{C}$ and then through a column of granular calcium sulfate. Solvents for the deallylation and the synthesis of $\mathrm{Ru}$ complexes were dried, degassed at reflux temperature in the presence of the following appropriate drying agents $(250 \mathrm{mg} / 100 \mathrm{~mL})$ under an Ar stream for $6 \mathrm{~h}$, and distilled into Schlenk flasks: calcium hydride for $i \mathrm{PrOH}, \mathrm{CH}_{2} \mathrm{Cl}_{2}, \mathrm{CH}_{3} \mathrm{CN}$ and $\mathrm{CD}_{3} \mathrm{CN}$; magnesium for $\mathrm{C}_{2} \mathrm{H}_{5} \mathrm{OH}, \mathrm{CH}_{3} \mathrm{OH}$ and $\mathrm{CD}_{3} \mathrm{OD}$; sodium for hexane, benzene and benzene- $d_{6}$; and MS4A for acetone, acetone- $d_{6},\left(\mathrm{CH}_{3}\right)_{2} \mathrm{CDOH}$ and $\left(\mathrm{CD}_{3}\right)_{2} \mathrm{CDOD}$. The solvent was degassed by three freezethaw cycles before deallylation. In a similar manner, diethyl ether, THF and THF- $d_{8}$ were distilled from sodium benzophenone ketyl $(3 \mathrm{~g} / \mathrm{L}) . \quad \mathrm{CDCl}_{3}$ was purchased from Cambridge Isotope Laboratories and purified by alumina column chromatography. It was degassed by three freeze-thaw cycles before use in the ${ }^{1} \mathrm{H}$ NMR study. All other solvents were obtained commercially and used without further purification unless stated otherwise.

Details for the deallylation procedure, the results of the allyloxy substrates in "section 2.4 on Generality," and the NMR data of the substrates and deprotected products have been reported in the supporting information of previous short communications. $^{7}$

\subsection{Ligand and CpM screening}

\subsubsection{Materials}

Ligands L1-L48 shown in Fig. 3 were as follows: picolinic acid (PAH, L1), hydroxy(pyridin-2-yl)methanesulfonic acid (L2), quinoline-8-sulfonyl chloride (L3), $1 H$-imidazole-4-carboxylic acid (L4), pyridine-2,6-dicarboxylic acid (L5), $1 \mathrm{H}$ benzo[ $d]$ imidazole-2-sulfonic acid (L6), pyridin-2-ylmethanol (L7), 2-((dimethylamino)methyl)pyridin-3-ol (L8), (Z)picolinaldehyde oxime (L9), 3H-[1,2,3]triazolo[4,5-b]pyridin-3ol (L10), 1H-benzo[d][1,2,3]triazol-1-ol (L11), pyridin-2-ol (L12), quinolin-8-ol (L13), 5-chloroquinolin-8-ol (L14), 8hydroxyquinoline-5-sulfonic acid (L15), 5-nitroquinolin-8-ol (L16), 5-(chloro- $\lambda^{5}$-azanyl)quinolin-8-ol hydrochloride (L17), 2(benzo[ $d]$ oxazol-2-yl)phenol (L18), pyridin-2-ylmethanamine (L19), picolinamide (L20), [2,2':6',2"-terpyridin]-4'(1'H)-one (L21), 2-(pyridin-2-yl)-1H-benzo[d]imidazole (L22), 6ethoxybenzo[ $d]$ thiazole-2-sulfonamide (L23), 1H-pyrazole-1carboximidamide hydrochloride (L24), 2,2'-bipyridine (L25), pyridine (L26), glycine (L27), (S)-2-amino-3,3-dimethylbutanoic acid (L28), proline (L29), piperidine-2-carboxylic acid (L30), piperazine-2-carboxylic acid hydrochloride (L31), $1 H$-indole-2carboxylic acid (L32), 1H-pyrrole-2-carboxylic acid (L33), dimethylglycine (L34), methyl-L-proline (L35), 2-(diphenyl- 
phosphanyl)acetic acid (L36), 2-(diphenylphosphanyl)benzoic acid (L37), 2-(diphenylphosphanyl)ethan-1-ol (L38), 2-(diphenylphosphanyl)ethan-1-amine (L39), triphenylphosphane (L40), tricyclohexylphosphane (L41), (2-methoxyethyl)diphenylphosphane (L42), 2-(diphenylphosphanyl)- $N, N$-dimethylethan-1amine (L43), 2-(4-oxo-2-thioxothiazolidin-3-yl)acetic acid (L44), thianthren-1-ylboronic acid (L45), 2-(thiophen-2-yl)acetic acid (L46), benzo[b]thiophen-2-ylboronic acid (L47), and furan-2carboxylic acid (L48). Except for L36, all ligands were commercially purchased and used without further purification. L36 was synthesized according to a previously reported method. ${ }^{19}$

The ligands shown in Table 1 were as follows: benzoic acid, nicotinic acid, isonicotinic acid, sodium picolinate, methyl picolinate, quinoline-8-carboxylic acid, 4-methoxypicolinic acid (4- $\left.\mathrm{CH}_{3} \mathrm{O}-\mathrm{PAH}\right)$ 4-chloropicolinic acid (4-Cl-PAH), 4(trifluoromethyl)picolinic acid (4- $\left.\mathrm{CF}_{3}-\mathrm{PAH}\right)$, 4-nitropicolinic acid $\left(4-\mathrm{NO}_{2}-\mathrm{PAH}\right)$, pyridin-2-ylphosphonic acid $\left(\mathrm{PyPO}(\mathrm{OH})_{2}\right)$, pyridine-2-sulfonic acid $\left(\mathrm{PySO}_{3} \mathrm{H}\right)$, isoquinoline-1-carboxylic acid, isoquinoline-3-carboxylic acid, quinoline-2-carboxylic acid (QAH). Except for $\mathrm{PySO}_{3} \mathrm{H}$, all ligands were commercially purchased and used without further purification. $\mathrm{PySO}_{3} \mathrm{H}$ was prepared by a previously reported method. ${ }^{20}$

$\left[\mathrm{RuCp}\left(\mathrm{CH}_{3} \mathrm{CN}\right)_{3}\right] \mathrm{PF}_{6} \quad(\mathbf{1}), \quad\left[\mathrm{MoCp}(\mathrm{CO})_{3}\right]_{2}, \quad\left[\mathrm{WCp}(\mathrm{CO})_{3}\right]_{2}$, $\left[\mathrm{FeCp}(\mathrm{CO})_{3}\right]_{2}, \mathrm{RhCp}(\mathrm{cod})$, and $\mathrm{IrCp}(\mathrm{cod})$ were commercially purchased. Commercial 2-propen-1-ol (AllOH) and synthetic (2(allyloxy)ethyl)benzene $\left(\mathrm{C}_{6} \mathrm{H}_{5} \mathrm{CH}_{2} \mathrm{CH}_{2} \mathrm{OAll}(2)\right)^{21}$ were purified by distillation and stored in a Schlenk flask under Ar.

\subsubsection{Ligand screening in Fig. 3}

The Chemspeed ASW2000 (single syringe) system was customized for use under an inert atmosphere (see Supplementary Data), and Chemspeed-G735 software was used to program the screening. Five sets of reaction blocks, each containing 16 glass vials, were heated at $120^{\circ} \mathrm{C}$ for 30 min under a reduced pressure of $200 \mathrm{mmHg}$. To each of 48 vials, ligands L1-L48 (each $5.00 \mathrm{~mol}$ ) were manually added within a glovebox, and the temperature of the five reaction blocks was adjusted to $30{ }^{\circ} \mathrm{C}$. A $10.0 \quad \mathrm{mM}$ stock solution of $\left[\mathrm{RuCp}\left(\mathrm{CH}_{3} \mathrm{CN}\right)_{3}\right] \mathrm{PF}_{6}(\mathbf{1})$ in $\mathrm{CH}_{3} \mathrm{OH}(30 \mathrm{~mL})$, and three $111 \mathrm{mM}$ stock solutions of $\mathrm{C}_{6} \mathrm{H}_{5} \mathrm{CH}_{2} \mathrm{CH}_{2} \mathrm{OAll}$ (2) $(80 \mathrm{~mL} \times 3)$ were prepared in four $100-\mathrm{mL}$ vials in a storage tray. A $500-\mathrm{L}$ aliquot of solution $1(5.00 \mathrm{~mol})$ was first added to each $20-\mathrm{mL}$ reaction vessel, and then the single syringe needle was subjected to a 20 -sec outside/inside rinse with $\mathrm{CH}_{3} \mathrm{OH}$. Next, a $4.50-\mathrm{mL}$ aliquot of solution $2(500 \mathrm{~mol})$ was added to each of the vessels. All other reactions (L2-L48) were prepared in this way, taking ca. $1 \mathrm{~h}$. After being shaken at $30^{\circ} \mathrm{C}$ for $3 \mathrm{~h}$ from the start point of the first reaction (L1), the glovebox-type hood was opened, and a $200 \mathrm{~L}$ aliquot of the reaction mixture (L1) was placed in a $5-\mathrm{mL}$ vial of a sampling tray, and the syringe was cleaned by a 20-sec outside/inside rinse with $\mathrm{CH}_{3} \mathrm{OH}$. The sample was manually frozen by using liquid $\mathrm{N}_{2}$. All other samples, which were consecutively transferred from the corresponding reaction vessels every $75 \mathrm{sec}$, were frozen. Gas chromatography analyses of the samples were performed on Shimazu GC-14B and GC$17 \mathrm{~A}$ instruments with the following conditions: capillary column, J\&W Scientific DB-WAX $(0.25 \mathrm{~mm}$ x $15 \mathrm{~m})$; column temperature, $50-250{ }^{\circ} \mathrm{C}$; rate of temperature increase, $10^{\circ} \mathrm{C} / \mathrm{min}$; $t_{\mathrm{R}} 4.0 \min (2)$ and $6.0 \mathrm{~min}(3)$.

\subsubsection{Ligand optimization in Tables 1 and 2}

All reactions were carried out under Ar atmosphere by using a general Schlenk technique. Schlenk flasks were dried at ca. 250 ${ }^{\circ} \mathrm{C}$ by using a heat gun under reduced pressure, and a Teflon- coated magnetic bar was used to stir the reaction mixture. The typical procedure is represented by the reaction of entry 1 in Table 1: $\left[\mathrm{RuCp}\left(\mathrm{CH}_{3} \mathrm{CN}\right)_{3}\right] \mathrm{PF}_{6}(\mathbf{1})(1.60 \mathrm{mg}, 3.69 \mu \mathrm{mol})$ and $\mathrm{CH}_{3} \mathrm{OH}(0.330 \mathrm{~mL})$ were placed in a $20-\mathrm{mL}$ Schlenk tube under Ar stream. A $100 \mathrm{mM}$ solution of PAH $(0.0370 \mathrm{~mL}, 37.0 \mu \mathrm{mol})$ in $\mathrm{CH}_{3} \mathrm{OH}$ was added to the mixture. After standing for $30 \mathrm{~min}$ at $\mathrm{rt}$, the reddish brown solution was transferred into a $20-\mathrm{mL}$ Schlenk tube equipped with a Young's tap containing $\mathrm{C}_{6} \mathrm{H}_{5} \mathrm{CH}_{2} \mathrm{CH}_{2} \mathrm{OAll}$ (2) (300 mg, $\left.1.85 \mathrm{mmol}\right)$ and $\mathrm{CH}_{3} \mathrm{OH}(3.00$ $\mathrm{mL})$. The yellow solution was stirred for $1 \mathrm{~h}$ at $30^{\circ} \mathrm{C}$. GC analysis (conditions as above) was used to determine the yield of $\mathrm{C}_{6} \mathrm{H}_{5} \mathrm{CH}_{2} \mathrm{CH}_{2} \mathrm{OH}$ (3). Instead of $\mathbf{1}$ and $\mathrm{PAH}$, other $\mathrm{CpM}$ precursors and ligands were used.

\subsection{NMR experiments}

A dry and Ar-filled 5-mm Young-type NMR tube was charged with a $200-\mathrm{mM}\left(\mathrm{CD}_{3}\right)_{2} \mathrm{CO}$ solution of QAH $(0.500 \mathrm{~mL}, 100$ mol), and subjected to ${ }^{1} \mathrm{H}-\mathrm{NMR}$ analysis at $30{ }^{\circ} \mathrm{C}$ (Fig. 7a). After degassing the mixture by two freeze/thaw cycles, a 200 $\mathrm{mM}\left(\mathrm{CD}_{3}\right)_{2} \mathrm{CO}$ solution of $\left[\mathrm{RuCp}\left(\mathrm{CH}_{3} \mathrm{CN}\right)_{3}\right] \mathrm{PF}_{6}(\mathbf{1})(0.500 \mathrm{~mL}$, 100 mol) was added to the NMR tube under Ar atmosphere. After 10 min at $30{ }^{\circ} \mathrm{C}$, the ${ }^{1} \mathrm{H}-\mathrm{NMR}$ spectrum was recorded (Fig. 7b), and then a $500-\mathrm{mM}\left(\mathrm{CD}_{3}\right)_{2} \mathrm{CO}$ solution of $\mathrm{C}_{6} \mathrm{H}_{5} \mathrm{CH}_{2} \mathrm{CH}_{2} \mathrm{OAll}$ (2) $(0.200 \mathrm{~mL}, 100 \mathrm{~mol})$ was added. After $30 \mathrm{~min}$ at $30^{\circ} \mathrm{C}$, the ${ }^{1} \mathrm{H}-\mathrm{NMR}$ spectrum was recorded (Fig. 7c), and then 2 (162 mg, $1.00 \mathrm{mmol}$ ) and $\mathrm{CH}_{3} \mathrm{OH}(405 \mathrm{~L}, 320 \mathrm{mg}, 10.0 \mathrm{mmol})$ were added. After $12 \mathrm{~h}$ at $30{ }^{\circ} \mathrm{C}$, the final ${ }^{1} \mathrm{H}-\mathrm{NMR}$ spectrum was recorded (Fig. 7d). In a separate experiment, a 1:1 mixture of the deprotected alcohol, $\mathrm{C}_{6} \mathrm{H}_{5} \mathrm{CH}_{2} \mathrm{CH}_{2} \mathrm{OH}$ (3), and the co-product, $\mathrm{CH}_{3} \mathrm{OAll}$, showed $\mathrm{OCH}_{2}$ signals in a ca. 1:0.5 ratio.

\subsection{Kinetic experiments}

The allyl ether substrate $\mathrm{C}_{6} \mathrm{H}_{5} \mathrm{CH}_{2} \mathrm{CH}_{2} \mathrm{OAll}$ (2) and air- and moisture-stable $\left[\mathrm{RuCp}\left({ }^{3}-\mathrm{C}_{3} \mathrm{H}_{5}\right)(\mathrm{QA})\right] \mathrm{PF}_{6}(5)$ were used for the kinetic study. Three stock solutions of 2 in $\mathrm{CD}_{3} \mathrm{OD}$ at $333 \mathrm{mM}$ (S-I), $556 \mathrm{mM}$ (S-II), and $1.11 \mathrm{M}$ (S-III), and three stock solutions of 5 in $\mathrm{CD}_{3} \mathrm{OD}$ at $5.00 \mathrm{mM}$ (C-I), $10.0 \mathrm{mM}$ (C-II), and $20.0 \mathrm{mM}$ (C-III) were prepared in advance, and degassed by three freeze/thaw cycles. Five dried and Ar-filled 5-mm Youngtype NMR tubes were charged, respectively, with S-I (900 L, $300 \mathrm{~mol} \mathrm{2})$, three lots of S-II (900 L, $500 \mathrm{~mol} \mathrm{2})$, and S-III (900 L, $1.00 \mathrm{mmol} 2$ ), and then immersed in a dry ice $/ \mathrm{CH}_{3} \mathrm{OH}$ bath. To these tubes were added, C-I (100 L, $0.500 \mathrm{~mol}$ 5), three lots of C-II (100 L, $1.00 \mathrm{~mol})$, and C-III (100 L, 2.00 mol). Each of the five cooled S-I/C-II, S-II/C-II, S-III/C-II, SII/C-I, S-II/C-II combined systems was measured by ${ }^{1} \mathrm{H}-\mathrm{NMR}$ with the probe temperature adjusted to $30{ }^{\circ} \mathrm{C}$. FID was sampled every $5 \mathrm{~min}$ for $3 \mathrm{~h}$. The signal intensity at $3.77(2 \mathrm{H}, \mathrm{t}, J=$ $\left.7.57 \mathrm{~Hz}, \mathrm{C}_{6} \mathrm{H}_{5} \mathrm{CH}_{2} \mathrm{CH}_{2} \mathrm{OH}(3)\right)$ was plotted over time, and the rate was determined in the $0 \%-30 \%$ conversion range. ${ }^{15}$ In the early reaction stage, logarithmic plotting afforded high linearity to determine the following initial rates: $12.2 \mathrm{mM} / \mathrm{min}(\mathrm{S}-\mathrm{I} / \mathrm{C}-\mathrm{II})$, $12.4 \mathrm{mM} / \mathrm{min}$ (S-II/C-II), $12.6 \mathrm{mM} / \mathrm{min}$ (S-III/C-II), 8.32 $\mathrm{mM} / \mathrm{min}(\mathrm{S}-\mathbf{I I} / \mathrm{C}-\mathbf{I})$, and $26.3 \mathrm{mM} / \mathrm{min}(\mathrm{S}-\mathbf{I I} / \mathrm{C}-\mathbf{I I})$.

\subsection{Preparation of metal complexes and $X$-ray crystallographic analysis}

\subsection{1. $\left[\mathrm{RuCp}\left({ }^{3}-\mathrm{C}_{3} \mathrm{H}_{5}\right)\left(4-\mathrm{CH}_{3} \mathrm{O}-\mathrm{PA}\right)\right] \mathrm{PF}_{6}$}

A dry and Ar-filled 10-mL Schlenk flask was charged with $\left[\mathrm{RuCp}\left(\mathrm{CH}_{3} \mathrm{CN}\right)_{3}\right] \mathrm{PF}_{6}$ (1) $(3.21 \mathrm{mg}, 73.9 \mathrm{~mol}), 4-\mathrm{CH}_{3} \mathrm{O}-\mathrm{PAH}$ $(11.3 \mathrm{mg}, 73.8 \mathrm{~mol})$, and $\left(\mathrm{CH}_{3}\right)_{2} \mathrm{CO}(7.0 \mathrm{~mL})$ at rt. After the resulting yellow solution was stirred at $\mathrm{rt}$ for $5 \mathrm{~min}$, a $200-\mathrm{mM}$ $\left(\mathrm{CH}_{3}\right)_{2} \mathrm{CO}$ solution of AllOH (369 L, 73.7 mol) was introduced to the Schlenk flask. The resulting purple solution was cannulated into a $5-\mathrm{mL}$ tube placed in a $20-\mathrm{mL}$ Schlenk 
flask, and hexane $(3.0 \mathrm{~mL})$ was added to the Schlenk flask outside the $5-\mathrm{mL}$ tube. After sealing the system by using a silicone-greased glass stopper, the whole system was kept at $5{ }^{\circ} \mathrm{C}$ for $12 \mathrm{~h}$ to generate yellow prismatic crystals $(32.0 \mathrm{mg}, 63.5$ mol, 86\% yield): ${ }^{1} \mathrm{H}$ NMR $\left(\left(\mathrm{CD}_{3}\right)_{2} \mathrm{CO}\right) \quad 4.09$ (s, 3H, $\left.\mathrm{OCH}_{3}\right)$, 4.23 (dd, $\left.J=6.54,2.75 \mathrm{~Hz}, 1 \mathrm{H}, \mathrm{CH}_{\text {syn }}\right), 4.39$ (dd, $J=6.20,2.75$ $\left.\mathrm{Hz}, 1 \mathrm{H}, \mathrm{CH}_{\mathrm{syn}}\right), 4.46\left(\mathrm{~d}, J=11.02 \mathrm{~Hz}, 1 \mathrm{H}, \mathrm{CH}_{\text {anti }}\right), 4.60(\mathrm{~d}, J=$ $11.02 \mathrm{~Hz}, 1 \mathrm{H}, \mathrm{CH}_{\text {anti }}$ ), 4.86 (dddd, $J=11.02,11.02,6.20,6.20$ $\mathrm{Hz}, 1 \mathrm{H}, \mathrm{CH}_{\text {center }}$ ), 6.36 (s, 5H, Cp), 7.40 (dd, $J=6.54,2.75 \mathrm{~Hz}$, $1 \mathrm{H}, \mathrm{C}(5) \mathrm{H}), 7.45(\mathrm{~d}, J=2.75 \mathrm{~Hz}, 1 \mathrm{H}, \mathrm{C}(3) \mathrm{H}), 8.81(\mathrm{~d}, J=6.89$ $\mathrm{Hz}, 1 \mathrm{H}, \mathrm{C}(6) \mathrm{H}) ;{ }^{13} \mathrm{C} \mathrm{NMR}\left(\left(\mathrm{CD}_{3}\right)_{2} \mathrm{CO}\right) \quad 57.7,66.3,68.4,97.1$, 101.8, 114.2, 116.7, 152.4, 158.4, 170.8, 171.1; HRMS (ESI) $\mathrm{m} / \mathrm{z}$ : calcd for $\mathrm{C}_{15} \mathrm{H}_{16} \mathrm{NO}_{3} \mathrm{Ru}\left[\mathrm{M}-\mathrm{PF}_{6}\right]^{+}, 360.0174$; found, 360.0174; mp $186^{\circ} \mathrm{C}$ (decomposed).

Crystallographic data for the structures in this paper have been deposited with the Cambridge Crystallographic Data Centre. Copies of the data can be obtained, free of charge, on application to CCDC, 12 Union Road, Cambridge CB2 1EZ, UK (fax: +44(0)1223-336033 or e-mail: deposit@ccdc.cam.ac.Uk). RuCp( ${ }^{3}$ $\left.\left.\mathrm{C}_{3} \mathrm{H}_{5}\right)\left(4-\mathrm{CH}_{3} \mathrm{O}-\mathrm{PA}\right)\right] \mathrm{PF}_{6}$ is available as supplementary publication no. CCDC 1052811. Crystals of $\left[\mathrm{RuCp}\left({ }^{3}-\right.\right.$ $\left.\left.\mathrm{C}_{3} \mathrm{H}_{5}\right)(\mathrm{PA})\right] \mathrm{PF}_{6}, \quad\left[\mathrm{RuCp}\left({ }^{3}-\mathrm{C}_{3} \mathrm{H}_{5}\right)(4-\mathrm{Cl}-\mathrm{PA})\right] \mathrm{PF}_{6}, \quad\left[\mathrm{RuCp}\left({ }^{3}-\right.\right.$ $\left.\left.\mathrm{C}_{3} \mathrm{H}_{5}\right)\left(4-\mathrm{CF}_{3}-\mathrm{PA}\right)\right] \mathrm{PF}_{6}$, and $\left[\mathrm{RuCp}\left({ }^{3}-\mathrm{C}_{3} \mathrm{H}_{5}\right)\left(4-\mathrm{NO}_{2}-\mathrm{PA}\right)\right] \mathrm{PF}_{6}$ were prepared in the same way.

\subsection{2. $\left[R u C p\left({ }^{3}-C_{3} H_{5}\right)(P A)\right] P F_{6}$}

Conditions: $\left[\mathrm{RuCp}\left(\mathrm{CH}_{3} \mathrm{CN}\right)_{3}\right] \mathrm{PF}_{6}(\mathbf{1})(32.0 \mathrm{mg}, 73.7 \mathrm{~mol})$, PAH $(9.01 \mathrm{mg}, 73.2 \mathrm{~mol}),\left(\mathrm{CH}_{3}\right)_{2} \mathrm{CO}(7.00 \mathrm{~mL})$, a $200-\mathrm{mM}$ $\left(\mathrm{CH}_{3}\right)_{2} \mathrm{CO}$ solution of $\mathrm{AllOH}(369 \mathrm{~L}, 73.7 \mathrm{~mol})$. [RuCp( ${ }^{3}-$ $\left.\mathrm{C}_{3} \mathrm{H}_{5}\right)(\mathrm{PA}) \mathrm{PF}_{6}(31.3 \mathrm{mg}, 66.0 \mathrm{~mol}, 90 \%$ yield) as yellow prismatic crystals: ${ }^{1} \mathrm{H}$ NMR $\left(\left(\mathrm{CD}_{3}\right)_{2} \mathrm{CO}\right) \quad 4.27(\mathrm{dd}, J=6.54$, $\left.2.75 \mathrm{~Hz}, 1 \mathrm{H}, \mathrm{CH}_{\mathrm{syn}}\right), 4.45\left(\mathrm{dd}, J=6.20,2.75 \mathrm{~Hz}, 1 \mathrm{H}, \mathrm{CH}_{\mathrm{syn}}\right), 4.50$ (d, $\left.J=11.02 \mathrm{~Hz}, \mathrm{CH}_{\text {anti }}\right), 4.66\left(\mathrm{~d}, J=10.33 \mathrm{~Hz}, 1 \mathrm{H}, \mathrm{CH}_{\text {anti }}\right), 4.94$ (dddd, $J=11.02,11.02,6.20,6.20 \mathrm{~Hz}, 1 \mathrm{H}, \mathrm{CH}_{\text {center }}$ ), 6.39 (s, $5 \mathrm{H}$, Cp), 7.89 (dd, $J=6.89,6.20 \mathrm{~Hz}, \mathrm{C}(5) \mathrm{H}), 7.99$ (d, $J=8.26 \mathrm{~Hz}$, $1 \mathrm{H}, \mathrm{C}(3) \mathrm{H}), 8.35(\mathrm{dd}, J=7.57,7.57 \mathrm{~Hz}, 1 \mathrm{H}, \mathrm{C}(4) \mathrm{H}), 9.08(\mathrm{~d}, J=$ $5.51 \mathrm{~Hz}, 1 \mathrm{H}, \mathrm{C}(6) \mathrm{H}) ;{ }^{13} \mathrm{C}$ NMR $\left(\left(\mathrm{CD}_{3}\right)_{2} \mathrm{CO}\right) \quad 66.4,69.3,97.4$, $101.9,128.9,130.5,142.9,151.0,158.2,171.3$; HRMS (ESI) $m / z$ : calcd for $\mathrm{C}_{14} \mathrm{H}_{14} \mathrm{NO}_{2} \mathrm{Ru}\left[\mathrm{M}-\mathrm{PF}_{6}\right]^{+}, 330.0068$; found, 330.0090; $\mathrm{mp} 210{ }^{\circ} \mathrm{C}$ (decomposed). Crystallographic data no. CCDC 1052813.

\subsection{3. $\left[\mathrm{RuCp}\left({ }^{3}-\mathrm{C}_{3} \mathrm{H}_{5}\right)(4-\mathrm{Cl}-\mathrm{PA})\right] \mathrm{PF}_{6}$}

Conditions: $\left[\mathrm{RuCp}\left(\mathrm{CH}_{3} \mathrm{CN}\right)_{3}\right] \mathrm{PF}_{6}$ (1) (32.2 mg, $\left.74.1 \mathrm{~mol}\right)$, 4Cl-PAH (11.6 mg, $73.7 \mathrm{~mol}),\left(\mathrm{CH}_{3}\right)_{2} \mathrm{CO}(7.0 \mathrm{~mL})$, a $200-\mathrm{mM}$ $\left(\mathrm{CH}_{3}\right)_{2} \mathrm{CO}$ solution of AllOH (369 L, $\left.73.7 \mathrm{~mol}\right)$. [RuCp( ${ }^{3}-$ $\left.\mathrm{C}_{3} \mathrm{H}_{5}\right)(4-\mathrm{Cl}-\mathrm{PA}) \mathrm{PF}_{6}(37.5 \mathrm{mg}, 60.1 \mathrm{~mol}, 82 \%$ yield) as yellow prismatic crystals: ${ }^{1} \mathrm{H}$ NMR $\left(\left(\mathrm{CD}_{3}\right)_{2} \mathrm{CO}\right) \quad 4.29(\mathrm{dd}, J=6.89$, $\left.2.75 \mathrm{~Hz}, 1 \mathrm{H}, \mathrm{CH}_{\text {syn }}\right), 4.48\left(\mathrm{dd}, J=6.20,2.75 \mathrm{~Hz}, 1 \mathrm{H}, \mathrm{CH}_{\text {syn }}\right), 4.52$ (d, $\left.J=11.02 \mathrm{~Hz}, 1 \mathrm{H}, \mathrm{CH}_{\text {anti }}\right), 4.69\left(\mathrm{~d}, J=11.02 \mathrm{~Hz}, 1 \mathrm{H}, \mathrm{CH}_{\text {anti }}\right)$, 5.02 (dddd, $J=11.02,11.02,6.89,6.20 \mathrm{~Hz}, 1 \mathrm{H}, \mathrm{CH}_{\text {center }}$ ), 6.41 (s, $5 \mathrm{H}, \mathrm{Cp}), 7.96$ (d, $J=2.75 \mathrm{~Hz}, 1 \mathrm{H}, \mathrm{C}(3) \mathrm{H}), 8.00$ (dd, $J=6.20$, $2.75 \mathrm{~Hz}, 1 \mathrm{H}, \mathrm{C}(5) \mathrm{H}), 9.05(\mathrm{~d}, J=6.20 \mathrm{~Hz}, 1 \mathrm{H}, \mathrm{C}(6) \mathrm{H}) ;{ }^{13} \mathrm{C} \mathrm{NMR}$ $\left(\left(\mathrm{CD}_{3}\right)_{2} \mathrm{CO}\right) \quad 66.6,69.6,97.4,102.1,128.7,130.4,150.7,152.2$, 158.8, 170.3; HRMS (ESI) $\mathrm{m} / \mathrm{z}$ : calcd for $\mathrm{C}_{14} \mathrm{H}_{13} \mathrm{ClNO}_{2} \mathrm{Ru}[\mathrm{M}-$ $\left.\mathrm{PF}_{6}\right]^{+}$, 363.9678; found, 363.9703; mp $216{ }^{\circ} \mathrm{C}$ (decomposed). Crystallographic data no. CCDC 1052810.

4.5.4. $\left[R u C p\left({ }^{3}-C_{3} H_{5}\right)\left(4-C_{3}-P A\right)\right] P F_{6}$

Conditions: $\left[\mathrm{RuCp}\left(\mathrm{CH}_{3} \mathrm{CN}\right)_{3}\right] \mathrm{PF}_{6}$ (1) $(32.1 \mathrm{mg}, 73.9 \mathrm{~mol}), 4-$ $\mathrm{CF}_{3}$-PAH (14.1 mg, $\left.73.8 \mathrm{~mol}\right),\left(\mathrm{CH}_{3}\right)_{2} \mathrm{CO}(7.0 \mathrm{~mL})$, a $200-\mathrm{mM}$ $\left(\mathrm{CH}_{3}\right)_{2} \mathrm{CO}$ solution of $\mathrm{AllOH}(369 \mathrm{~L}, 73.7 \mathrm{~mol})$. [RuCp( ${ }^{3}-$ $\left.\left.\mathrm{C}_{3} \mathrm{H}_{5}\right)\left(4-\mathrm{CF}_{3}-\mathrm{PA}\right)\right] \mathrm{PF}_{6}(30.1 \mathrm{mg}, 55.6 \mathrm{~mol}, 75 \%$ yield $)$ as yellow prismatic crystals: ${ }^{1} \mathrm{H}$ NMR $\left(\left(\mathrm{CD}_{3}\right)_{2} \mathrm{CO}\right) \quad 4.34(\mathrm{dd}, J=6.46$, $\left.2.75 \mathrm{~Hz}, 1 \mathrm{H}, \mathrm{CH}_{\mathrm{syn}}\right), 4.53\left(\mathrm{dd}, J=5.93,2.75 \mathrm{~Hz}, 1 \mathrm{H}, \mathrm{CH}_{\mathrm{syn}}\right), 4.56$ (d, $\left.J=11.02 \mathrm{~Hz}, 1 \mathrm{H}, \mathrm{CH}_{\text {anti }}\right), 4.75\left(\mathrm{~d}, J=11.02 \mathrm{~Hz}, 1 \mathrm{H}, \mathrm{CH}_{\text {anti }}\right)$,
5.07 (dddd, $\left.J=11.02,11.02,6.89,6.20 \mathrm{~Hz}, 1 \mathrm{H}, \mathrm{CH}_{\text {center }}\right), 6.43$ (s, $5 \mathrm{H}, \mathrm{Cp}), 8.15(\mathrm{~d}, J=2.07 \mathrm{~Hz}, 1 \mathrm{H}, \mathrm{C}(3) \mathrm{H}), 8.23(\mathrm{dd}, J=5.51$, $2.07 \mathrm{~Hz}, 1 \mathrm{H}, \mathrm{C}(5) \mathrm{H}), 9.40(\mathrm{~d}, J=6.20 \mathrm{~Hz}, 1 \mathrm{H}, \mathrm{C}(6) \mathrm{H}) ;{ }^{13} \mathrm{C} \mathrm{NMR}$ $\left(\left(\mathrm{CD}_{3}\right)_{2} \mathrm{CO}\right) \quad 66.7,70.2,97.5,102.2,124.2,126.1,142.9$ (q, $J=$ $141.4 \mathrm{~Hz}$ ), 152.9 (2C), 160.0, 170.2; HRMS (ESI) $\mathrm{m} / \mathrm{z}$ : calcd for $\mathrm{C}_{15} \mathrm{H}_{13} \mathrm{~F}_{3} \mathrm{NO}_{2} \mathrm{Ru}$ [M-PF $]^{+}$, 397.9942; found, 397.9968; mp 182 ${ }^{\circ} \mathrm{C}$ (decomposed). Crystallographic data no. CCDC 1052809.

\subsection{5. $\left[\mathrm{RuCp}\left({ }^{3}-\mathrm{C}_{3} \mathrm{H}_{5}\right)\left(4-\mathrm{NO}_{2}-\mathrm{PA}\right)\right] \mathrm{PF}_{6}$}

Conditions: $\left[\mathrm{RuCp}\left(\mathrm{CH}_{3} \mathrm{CN}\right)_{3}\right] \mathrm{PF}_{6}(1)(32.0 \mathrm{mg}, 73.7 \mathrm{~mol})$, 4$\mathrm{NO}_{2}$-PAH $(12.4 \mathrm{mg}, 73.8 \mathrm{~mol}),\left(\mathrm{CH}_{3}\right)_{2} \mathrm{CO}(7.0 \mathrm{~mL})$, a $200-\mathrm{mM}$ $\left(\mathrm{CH}_{3}\right)_{2} \mathrm{CO}$ solution of AllOH $(369 \mathrm{~L}, 73.7 \mathrm{~mol})$. [RuCp( ${ }^{3}$ $\left.\left.\mathrm{C}_{3} \mathrm{H}_{5}\right)\left(4-\mathrm{NO}_{2}-\mathrm{PA}\right)\right] \mathrm{PF}_{6}(22.2 \mathrm{mg}, 42.8 \mathrm{~mol}, 58 \%$ yield $)$ as yellow prismatic crystals: ${ }^{1} \mathrm{H}$ NMR $\left(\left(\mathrm{CD}_{3}\right)_{2} \mathrm{CO}\right) \quad 4.37$ (dd, $J=$ 6.54, $\left.2.75 \mathrm{~Hz}, 1 \mathrm{H}, \mathrm{CH}_{\mathrm{syn}}\right), 4.55$ (dd, $J=6.20,2.75 \mathrm{~Hz}, 1 \mathrm{H}$, $\left.\mathrm{CH}_{\text {syn }}\right), 4.60\left(\mathrm{~d}, J=11.02 \mathrm{~Hz}, 1 \mathrm{H}, \mathrm{CH}_{\text {anti }}\right), 4.78(\mathrm{~d}, J=11.02 \mathrm{~Hz}$, $1 \mathrm{H}, \mathrm{CH}_{\text {anti }}$ ), 5.09 (dddd, $J=11.71,11.02,6.89,6.20 \mathrm{~Hz}, 1 \mathrm{H}$, $\left.\mathrm{CH}_{\text {center }}\right), 6.46$ (s, 5H, Cp), $8.43(\mathrm{~d}, J=2.75 \mathrm{~Hz}, 1 \mathrm{H}, \mathrm{C}(3) \mathrm{H}), 8.56$ (dd, $J=6.20,2.75 \mathrm{~Hz}, 1 \mathrm{H}, \mathrm{C}(5) \mathrm{H}), 9.53(\mathrm{~d}, J=6.20 \mathrm{~Hz}, 1 \mathrm{H}$, $\mathrm{C}(6) \mathrm{H}) ;{ }^{13} \mathrm{C}$ NMR $\left(\left(\mathrm{CD}_{3}\right)_{2} \mathrm{CO}\right) \quad 66.8,70.7,97.6,102.4,121.0$, $122.9,154.3,157.8,161.1,169.8$; HRMS (ESI) $\mathrm{m} / \mathrm{z}$ : calcd for $\mathrm{C}_{14} \mathrm{H}_{13} \mathrm{~N}_{2} \mathrm{O}_{4} \mathrm{Ru}$ [M-PF $]^{+}$, 374.9919; found, 374.9933; mp $172{ }^{\circ} \mathrm{C}$ (decomposed). Crystallographic data no. CCDC 1052812.

\section{Acknowledgments}

This work was supported by a Grant-in-Aid for Scientific Research (No. 25410112, 24106713) and Platform for Drug Discovery, Informatics, and Structural Life Science from the Ministry of Education, Culture, Sports, Science and Technology (Japan), and an Advanced Catalytic Transformation Program for Carbon Utilization (ACT-C) from Japan Science and Technology Agency (JST).

\section{References and notes}

1. (a) Protective Groups in Organic Synthesis, 3rd ed.; Greene, T W., Wuts, P. G. M., Eds.; Wiley-VCH: New York, U.S.A., 2000; (b) Schelhaas, M.; Waldmann, H. Angew. Chem., Int. Ed. Engl. 1996, 35, 2056.

2. Corey, E. J.; Suggs, J. W. J. Org. Chem. 1973, 38, 3224.

3. (a) Oltvoort, J. J.; van Boeckel, C. A. A.; de Koning, J. H.; van Boom, J. H. Synthesis 1981, 305; For other isomerization-based methods, see: (b) Cadot, C.; Dalko, P. I.; Cossy, J. Tetrahedron Lett. 2002, 43, 1839; (b) Nicolaou, K. C.; Hummel, C. W.; Bockovich, N. J.; Wong, C.-H. J. Chem. Soc., Chem. Commun. 1991, 870; (c) Boss, R.; Scheffold, R. Angew. Chem., Int. Ed. Engl. 1976, 15, 558; (d) Cunningham, J.; Gigg, R.; Warren, C. D. Tetrahedron Lett. 1964, 1191

4. (a) Vutukuri, D. R.; Bharathi, P.; Yu, Z.; Rajasekaran, K.; Tran, M.-H.; Thayumanavan, S. J. Org. Chem. 2003, 68, 1146; (b) Chandrasekhar, S.; Reddy, C. R.; Rao, R. J. Tetrahedron 2001, 57, 3435; (c) Honda, M.; Morita, H.; Nagakura, I. J. Org. Chem. 1997, 62, 8932; (d) Beugelmans, R.; Bourdet, S.; Bigot, A.; Zhu, J. Tetrahedron Lett. 1994, 35, 4349.

5. Taniguchi, T.; Ogasawara, K. Angew. Chem., Int. Ed. 1998, 37, 1136.

6. Kitov, P. I.; Bundle, D. R. Org. Lett. 2001, 3, 2835.

7. (a) Tanaka, S.; Saburi, H.; Ishibashi, Y.; Kitamura, M. Org. Lett. 2004, 6, 1873; (b) Saburi, H.; Tanaka, S.; Kitamura, M. Angew. Chem., Int. Ed. 2005, 44, 1730; (c) Tanaka, S.; Saburi, H.; Kitamura, M. Adv. Synth. Catal. 2006, 348, 375; (d) Tanaka, S.; Saburi, H.; Murase, T.; Yoshimura, M.; Kitamura, M. J. Org. Chem. 2006, 71, 4682; (e) Tanaka, S.; Saburi, H.; Murase, T.; Ishibashi, Y.; Kitamura, M. J. Organomet. Chem. 2007, 692, 295; (f) Tanaka, S.; Hirakawa, T.; Oishi, K.; Hayakawa, Y.; Kitamura, M. Tetrahedron Lett. 2007, 48, 7320; (g) Tanaka, S.; Saburi, H.; Hirakawa, T.; Seki, T.; Kitamura, M. Chem. Lett. 2009, 38, 188; (h) Hirakawa, T.; Tanaka, S.; Usuki, N.; Kanzaki, H.; Kishimoto, M.; Kitamura, M. Eur. J. Org. Chem. 2009, 789-792.

8. (a) Noyori, R.; Kitamura, M. Angew. Chem., Int. Ed. Engl. 1991, 30, 49-69; For the original reaction deducing Intramol-MDACat 
concept, see: (b) Kitamura, M.; Suga, S.; Kawai, K.; Noyori, R. J. Am. Chem. Soc. 1986, 108, 6071-6072.

9. Some examples for hydrogenation: (a) Ohkuma, T.; Ooka, H.; Hashiguchi, S.; Ikariya, T.; Noyori, R. J. Am. Chem. Soc. 1995, 117, 2675; (b) Noyori R.; Ohkuma, T. Angew. Chem., Int. Ed. 2001, 40, 40; (c) H. Huang, T. Okuno, K. Tsuda, M. Yoshimura, M. Kitamura, J. Am. Chem. Soc. 2006, 128, 8716-8717; (d) Yamamura, T.; Nakatsuka, H.; Tanaka, S.; Kitamura, M. Angew. Chem. Int. Ed. 2013, 52, 1; Transfer hydrogenation: (e)

Hashiguchi, S.; Fujii, A.; Takehara, J.; Ikariya, T.; Noyori, R. J. Am. Chem. Soc. 1995, 117, 7562 .

10. (a) Nakano, K.; Bessho, Y.; Kitamura, M. Chem. Lett. 2003, 32, 224; (b) Kitamura, M.; Miki, T.; Nakano, K.; Noyori, R. Bull. Chem. Soc. Jpn. 2000, 73, 999 .

11. Bifunctional Molecular Catalysis; Ikariya, T., Shibasaki, M., Eds.; Springer: Heidelberg, Germany, 2011.

12. (a) Noyori, R.; Kitamura, M.; Ohkuma, T. Proc. Natl. Acad. Sci. U. S. A. 2004, 101, 5356; (b) Kitamura, M.; Nakatsuka, H. Chem. Commun. 2011, 47, 842. For the original reaction deducing Intermol-MDACat, see: (c) Noyori, R.; Ohkuma, T.; Kitamura, M.; Takaya, H.; Sayo, N.; Kumobayashi, H.; Akutagawa, S. J. Am. Chem. Soc. 1987, 109, 5856; (d) Kitamura, M.; Ohkuma, T.; Inoue, S.; Sayo, N.; Kumobayashi, H.; Akutagawa, S.; Ohta, T.; Takaya, H.; Noyori, R. J. Am. Chem. Soc. 1988, 110, 629.

13. (a) Kitamura, M.; Tanaka, S.; Yoshimura, M. J. Org. Chem. 2002 67, 4975-4977; For the first report on the utility or Cp*Ru complex in -allyl chemistry, see: (b) Kondo, T.; Ono, H.; Satake, N.; Mitsudo, T.; Watanabe, Y. Organometallics 1995, 14, 1945; For the subsequent related reports, see: (c) Trost, B. M.; Fraisse, P. L.; Ball, Z. T. Angew. Chem., Int. Ed. 2002, 41, 1059;

(d) Mbaye, M. D.; Demerseman, B.; Renaud, J.-L.; Toupet, L.;
Bruneau, C. Angew. Chem., Int. Ed. 2003, 42, 5066; (e) Burger, E. C.; Tunge, J. A. Org. Lett. 2004, 6, 2603; (f) Hermatschweiler, R.; Fernández, I.; Breher, F.; Pregosin, P. S.; Veiros, L. F.; Calhorda, M. J. Angew. Chem., Int. Ed. 2005, 44, 4397.

14. Books for automated synthesis and catalyst screening: (a) Applied Homogeneous Catalysis; Behr, A., Neubert, P., Eds.; Wiley-VCH: Weinheim, Germany, 2012; (b) Micro Instrumentation for High Throughpur Experimentation and Process Intensification-a Tool of PAT; Koch, M. V., VandenBussche, K. M., Chrisman, R. W., Eds.; Wiley-VCH: Weinheim, Germany, 2007; (c) Principles and Methods for Accelerated Catalyst Design and Testing; Derouane, E.G., Parmon, V., Lemos, F., Ribeiro, F. R., Eds.; Kluwer Academic Publishers: Dordrecht, 2002.

15. For details, see supplementary data.

16. Wuu, Y.-M.; Wrighton, M. S. Organometallics 1988, 7, 1839.

17. Dictionary of Organic Compounds, 6th ed. vol. 6; Buckingham, J., Macdonald, F., Eds.; Chapman \& Hall: London, UK, 1996.

18. Some examples of asymmetric allylation established on the basis of RDACat concept: (a) Miyata, K.; Kutsuna, H.; Kawakami, S.; Kitamura, M. Angew. Chem., Int. Ed. 2011, 50, 4649; Tanaka, T. Seki, M. Kitamura. Angew. Chem., Int. Ed. 2009, 48, 8948; (c) Seki, T.; Tanaka, S.; Kitamura, M. Org. Lett. 2012, 14, 608; (d) Miyata, K.; Kitamura, M. Synthesis 2012, 44, 2138; (e) Kitamura, M.; Miyata, K.; Seki, T.; Vatmurge, N.; Tanaka, S. Pure Appl. Chem. 2013, 85, 1121.

19. Refosco, F.; Tisato, F.; Bandoli, G.; Deutsch, E. J. Chem. Soc., Dalton Trans. 1993, 2901-2908.

20. den Hertog, H. J.; van der Plas, H. C.; Buurman, D. J. Recueil 1958, 77, 963-972.

21. Hill, C. M.; Simmons, D. E.; Hill, M. E. J. Am. Chem. Soc. 1955 77, 3889-3892. 
Graphical Abstract

To create your abstract, type over the instructions in the template box below.

Fonts or abstract dimensions should not be changed or altered.

Soft Ruthenium and Hard Brønsted Acid

Combined Catalyst for Efficient Cleavage of Allyloxy Bonds. Application to Protecting

Shinji Tanaka, Yusuke Suzuki, Hajime Saburi, Masato Kitamura*

Graduate School of Pharmaceutical Sciences, Graduate School of Science, and Research Center for Materials Science, Nagoya University, Chikusa, Nagoya 464-8601, Japan

cat:

$$
\begin{aligned}
& \text { ROm } \\
& \underset{\mathrm{CH}_{3} \mathrm{OH}}{\stackrel{\text { cat }}{\longrightarrow}} \mathrm{ROH}
\end{aligned}
$$

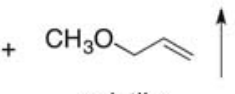

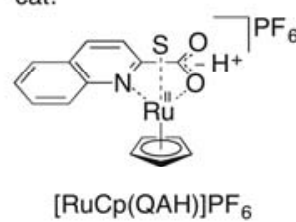

or

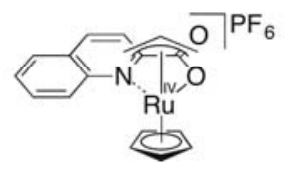

$\left[\mathrm{RuCp}\left(\eta_{3}-\mathrm{C}_{3} \mathrm{H}_{5}\right)(\mathrm{QA})\right] \mathrm{PF}_{6}$

TON up to $1,000,000$ 